\title{
Why the Management of The Ecclesiastic Estates In The Lands in the Lleida Area Hindered Agrarian Development In Western Catalonia? Natural Environment, Property, Politics and Social Conflict (1780-1960)
}

\author{
Enric Vicedo-Rius ${ }^{1}$ \\ ${ }^{1}$ Departament d'Història, Universitat de Lleida, Catalonia, Spain. \\ Correspondence: Enric Vicedo-Rius, Universitat de Lleida, Departament d'Història, Plaça Víctor Siurana, 1, 25003 \\ Lleida, Catalunya, Spain.
}

Received: February 17, 2016

Accepted: March 9, 2016

Available online: March 14, 2016

doi:10.11114/ijsss.v4i4.1460

URL: http://dx.doi.org/10.11114/ijsss.v4i4.1460

\begin{abstract}
In contrast with what was habitual in Catalonia, on the western plain around Lleida, there were large seigniorial, mainly ecclesiastical, estates that were not split up and awarded to smallholders and landless peasants in the liberal agrarian reform. The aim of this study is to analyse the management of these large properties at two historic moments: the final phase of the seigniorial regime (1780-1850) and the stage of the development of capitalist social relations (1850-1960) to attempt to understand why the management in this latter phase was insufficient to guarantee economic growth that would undoubtedly have benefited not only the property, but also the peasantry who worked it and western Catalonia as a whole.
\end{abstract}

Keywords: Estates, sharecroppers, access to the land, growth, western Catalonia, $18^{\text {th }}-20^{\text {th }}$ centuries.

\section{Approach to the Problem and First Hypothesis}

This study is aimed at explaining why the management of the large ecclesiastical estates on the western Catalan plain hindered, more than favoured, the economic development of this area of Catalonia. Catalonia is a self-governing region of Spain in the northeast of the Iberian Peninsula. Historically, the northern Iberian Peninsula is an area of smallholdings, little peasant farms, and in fact, that can be extended to Catalonia as a whole (Garrabou, 1992, ed.; Dios, 1999, ed. 2002, ed.; Garrabou et al, 2011; Garrabou, Planas, Saguer, \& Vicedo, 2014). However, exceptionally, in the area covered by this study, along with small and medium sized peasant holdings, there were large feudal estates, mainly in the hands of ecclesiastical lords (Vicedo-Rius, 1991).

In European historiography, the debate about whether large or small agrarian holdings can better generate economic growth has already been concluded. ${ }^{1}$ Both may or may not generate it depending on various economic-social variables, such as environmental factors and their management, human and financial resources, the initiative to meet the demands of the market, the weight of the seigniorial charges or the impact of income on leases. Consequently, our hypothesis considers that it was not the existence of large estates as such, or that these are mainly in ecclesiastical hands, that generated difficulties. Although the disentailment of Mendizábal (1836-1841) expropriated church lands, the fundamental reasons for this the difficulties of the Spanish exchequer and to reduce the power of a group that was very contrary to reforms (Rueda-Hernanz, 1997). In theory, the large estates in the region of Lleida could undoubtedly be worked rationally, with the adequate technical improvements, under the new capitalist system that consolidated the liberal

\footnotetext{
${ }^{1}$ For example, in contrast with classic interpretations, where the leading role was played by the enclosures, it has been shown that, until the 1840s it was the openfields, with their small and medium size peasant properties, where the crop rotations that characterized the English agricultural revolution were introduced. Allen, R. (1991). "The Two English Agricultural Revolutions, 1450-1850", in B.H.S. Campbell and M. Overton (eds.), Land, Labor, and Livestock, pp. 236-254. UK, Manchester: Manchester U. P.; Allen, R. (2004). "Revolution in the Fields", in Allen, R., Revolución en los campos. La reinterpretación de la revolución agrícola inglesa, p. 11-32. Monografías de la Sociedad Española de Historia Agraria. Spain, Zaragoza: Prensas Universitarias de la Universidad de Zaragoza. Joan Thirsk, analysing the 1640-1750 period, shows that small English peasant farmers also innovated and included more remunerative crops. "Agricultural Innovations and Their Diffusions, 1640-1750", in Thrisk, J. (1990, ed.), Agricultural Change: Policy and Practice, 1500-1750. USA, New York: Cambridge University Press, pp. 263-319. Hopcroft, R. L. (1999). "Rural Institutions and Agrarian Change in England", in Regions, Institutions, and Agrarian Change in European History. USA: University of Michigan, pp. 58-89.
} 
agrarian reform. Our initial hypothesis pointed towards an ongoing management of the estates little different from that of the Old Regime. This was aimed, not at improving agriculture and increasing the income of the property, but rather to guaranteeing a minimum income that, given the number of hectares owned, would let the landowners live comfortably.

In the times of the disentailment of Mendizábal, there were sectors of the Spanish intellectual class favourable to the lands of the large estates being shared among the peasants who had little or no land of their own. One of the great economists, Álvaro Flórez Estrada, proposed applying contracts similar to the emphyteusis. In Catalonia (Flórez, 1836), this contract guaranteed the stability of the peasantry on the land, awarding the useful domain in perpetuity, or for periods of longer than a generation, through the payment of rents to the holders of the direct domain (Serra, 1983). The studies of Catalan agrarian history have shown that this stability encouraged the introduction of improvements on the small and medium sized peasant holdings. For example, the development of vine growing and the trade in wine and spirits (Vilar, 1966).

In the Lleida area, enlightened sectors also called for the lands of the great estates to be shared out among the peasantry. Our hypothesis is that this option would surely have meant a progressive improvement of the agrarian holding, given that the smallholders had historically shown a capacity for work and adequate farming knowledge. Given that, it may seem surprising that this option (the so-called French way) was not considered seriously by the Spanish authorities. The financial needs of the Spanish exchequer favoured the solutions that generated quick money, and left the "peasant reforms" for another occasion. ${ }^{2}$

Further below, we explain how a good part of these estates expropriated from the Chapter of Lleida Cathedral during the disentailment returned to ecclesiastic hands although not the same ones but rather now the beneficiaries of the cathedral itself. In this sense, it must be noted that the administration again entrusted the lands to ecclesiastical sectors that had shown no special signs of sensitivity towards agrarian change.

The second hypothesis refers to an inadequate use of the work factor in the exploitation of the large estates. The dominant contract during the period of study (both under the old and new regimes) was the farming licence, a form of sharecropping, permission to work a plot that, despite being set at three years, could be cancelled without previous notice with or without justification during a good part of the period. The licences from 1922 still stated that these were for three years, although only the first was obligatory. As has been shown in Catalan rural history (and also for other territories), sharecropping cannot necessarily be attributed with handicapping the development of farming (Garrabou, Planas, \& Saguer, 2001a). It was a contract that fitted in the social and economic realities in various ways. Our hypothesis is that, it being formulated as a farming licence was more of an impediment than a stimulation for agrarian economies. It resulted in the imposition by the owner of conditions that transferred all the expenses to the licensed farmer and, despite low payments in kind proportional to the production, the insecurity about the duration of the contract and the lack of or insufficient compensation for the improvements carried out discouraged investment by the lessee (sharecropper or farmer with license).

This study is divided into four parts. The first describes the principal historical characteristics of the western Catalan plain. In the second, we analyse the economy of the large estates studied during the final stage of the seigniorial regime and the impact on these of the Spanish liberal agrarian reform. In the third part, with a new institutional framework under which property rights in a capitalist society were clearly established, we look in depth into the management of these estates and analyse whether this was in line with the evolution of the technical knowledge and advances available. ${ }^{3}$ For this, it will be very useful to compare this with other uses of sharecropping on the western Catalan plain. Finally, a summary of the results obtained is presented.

\section{Historical characterization of the western Catalan plain.}

In Catalonia, the 18th-century growth in agriculture, that laid the ground for the industrial development in the last third of the century, was based on peasant farms. These were mainly small in both the Catalonia of the "masos" and in the areas with open lands (Congost, Planas, Saguer, \& Vicedo, 2010; Ferrer, 1987; Congost, 1990; Vicedo-Rius, 1991; Tello, 1995). The richest sectors of the peasantry earned their capital through exploiting the landless peasant or those with smallholdings, either through onerous leases (for example, sharecropping with high shares of fruit) and/or salaried work during the periods of more work in the harvest of the Mediterranean trilogy

On the plains of western Catalonia, the majority small and medium size peasants were the key players in the agrarian

\footnotetext{
2 Some time ago, Fontana indicated that the aim was to share land among the peasantry when the disentailment of the goods of the councils and other civil institutions (hospitals, etc.) took place. Fontana, J. "Mendizábal y la desamortización civil", Hacienda Pública Española, 27 (1974), 75-80; íd. (1973). Hacienda y Estado en la crisis final del Antiguo Régimen español: 1823-1833. Spain, Madrid: Instituto de Estudios Fiscales; íd. (1977). La revolución liberal (Política y hacienda, 1833-1845). Spain, Madrid: Instituto de Estudios Fiscales; íd. (1983). La crisis del Antiguo régimen, 1808-1833. Spani. Barcelona: Crítica.

3 This study is based on the sources of the ecclesiastical landowners. The documents of the families with farming licences have been lost.
} 
transformations from medieval times. ${ }^{4}$ After the $17^{\text {th }}$-century crisis, which meant a heavy depopulation of the territory and a recovery of farmland by the lords (principally ecclesiastic), from the $18^{\text {th }}$ century there were two stages of agrarian growth. The first (until mid-century) consisted of the recovery of farming on the land near the villages, that had suffered not only the $17^{\text {th }}$-century crisis but also the effects of the War of the Spanish Succession (1701-1714). A second phase, from 1750 on, was expansion of the farmed land into areas further from the villages and which were often poorer. $^{5}$

Despite high population growth, especially during the second half of the $18^{\text {th }}$ century (see table 1 ), and the partial colonisation of seigniorial lands to satisfy the local demand and that of the main towns on the Catalan coast, as Pierre Vilar states, at the end of the $18^{\text {th }}$ century, demographic pressure was still low on the western Catalan plains and there were large areas of unfarmed land.

Table 1. Population growth by periods, $1700-1800 \equiv 100$

\begin{tabular}{cccccccc}
\hline & $1700-13$ & $1714-38$ & $1739-1760$ & $1761-80$ & $1781-1800$ & $1761-1800$ & $1700-1800$ \\
\hline Lleida & 5.2 & 18.9 & 22.6 & 24.3 & 29.0 & 53.3 & 100.0 \\
Anglesola & 2.3 & 28.9 & 15.0 & 27.2 & 26.6 & 53.8 & 100.0 \\
Verdú & -4.9 & 27.7 & 15.3 & 38.6 & 23.2 & 61.8 & 100.0 \\
Belianes & & & 9.0 & 32.6 & 58.4 & 91.0 & 100.0 \\
Tàrrega & 25.0 & 28.3 & 1.1 & 25.4 & 20.1 & 45.6 & 100.0 \\
\hline
\end{tabular}

Source: Vicedo-Rius, E., 2007, "Les transformacions del món rural de les terres de Lleida. Els límits d'un creixement, segle XVIII", Estudis d'Història Agrària, Homenatge a Pierre Vilar, 20, 69-88.

The agro-climatic conditions on the western plains of Catalonia hinder the farming of the land. The land is often poor in nutrients, annual rainfall is only about $400 \mathrm{~mm}$, and a heavy potential evapotranspiration that generates a humidity index between 0.4 and 0.5 . There are extreme temperatures in both summer and winter, and a temperature range of about twenty degrees between the averages for the hottest and coldest months.

Some medieval origin canals (or partly even earlier) guaranteed better harvests in some areas, especially in the Segrià district around Lleida. The irrigation ditches in the Pinyana system and those with smaller irrigation areas, Fontanet and Torres de Segre were of great importance locally despite only irrigating a small proportion of the land in the district. The Urgell Canal (in the 1860s) and the Aragon and Catalonia Canal (from 1910) supposed a great expansion of irrigation, but this arrived after the liberal agrarian reform had already created an economic and social framework that was of little benefit for the poorest peasantry and those with less possibilities of owning property. ${ }^{6}$

The data in Table 2 refer to the small landowners in the city of Lleida who had, at most, 5 jornals of land, an area that, although partly irrigated, did not generally allow the reproduction of peasant family units. Only those who had between 4 and 5 jornals of irrigated land, and when prices, especially for market garden products, were high, would have found themselves in a favourable situation. Most had to round out their income as salaried workers in the periods of highest demand for labour in the cycle of the Mediterranean trilogy, either by leasing some plot or obtaining a licence to farm the lands in the ecclesiastical estates that surrounded the municipality of Lleida. The average area of jornals per owner went from 3.2 in 1716 to 2.6 in 1785 , falling to 2.3 in 1844 . This drop was especially acute in the $18^{\text {th }}$ century, in what we know of as the process of proletarisation or, in the stricter sense, of pauperisation.

Table 2. Land ownership in Lleida. Owners of 0 to 5 jornals [ 1 jornal $\equiv 0.44 \mathrm{Ha}$ ]

\begin{tabular}{lccccccc}
\hline & 1716 & 1785 & 1808 & 1825 & 1834 & 1840 & 1844 \\
\hline$\%$ of owners & 46 & 61 & 63 & 67 & 68 & 70 & 68 \\
\% of land & 15 & 23 & 23 & 26 & 26 & 27 & 26 \\
Jornals per owner & 3.2 & 2.6 & 2.5 & 2.3 & 2.3 & 2.3 & 2.3 \\
Index $1716 \equiv 100$ & 100.0 & 83.3 & 77.6 & 72.9 & 72.9 & 71.6 & 73.5 \\
Index $1808 \equiv 100$ & & & 100.0 & 93.9 & 93.9 & 92.3 & 94.7 \\
\hline
\end{tabular}

Source: Vicedo-Rius, E. (1982), "Propietat, accés a la terra i distribució dels ingressos a la LLeida del segle XVIII", Recerques. Història. Economia. Cultura, 12, 57-90; Moreno, M. (1991), La pagesia lleidatana, 1808-1840, degree thesis. Estudi General de Lleida; Casals, Q. (1999), "Canvi econòmic i social en el pas de l'Antic Règim a l'Estat

\footnotetext{
4 The Town Charter awarded to Lleida in 1150 conceded land and resources to all the settlers. This resulted in the limits of Lleida being in the hands of smallholding peasants, mainly not under the seigniorial regime.

5 "La producció agrària", in Vicedo-Rius, E. (1991), Les terres de Lleida ..., chapter 2, 55-155.

6 The municipality of Lleida (21,200 ha) is nowadays irrigated by the Pinyana Canal (6,892 ha), the Fontanet irrigation ditch (973 ha), the Urgell Canal $(5,595 \mathrm{ha})$, the Aragon and Catalonia Canal $(6,768)$. There will also be the area of the Garrigues Baixes Canal (949 ha), currently under construction.
} 
Liberal: Lleida en la primera meitat del segle XIX”, Espai/Temps, 38. Spain, Lleida: Universitat de Lleida.

In contrast with what happened in other areas of Catalonia, the western Catalan plain was characterised by the presence of numerous large seigniorial estates, near Lleida and the surrounding villages, with a large number of peasants living in precarious conditions. While the population growth in the 18th century led to a process of proletarisation of the peasantry, with ever less land per family (as we have seen for Lleida), partially compensated for by the possibility of working some land on those estates, the socio-economic transformations in the first two-thirds of the 19th century did not solve the problem of the lack of resources among the small peasantry and rural proletariat.

This is an important question that lets us understand why western Catalonia plains did not develop agriculturally to allow a less subordinate integration into the capitalist development centred on Barcelona and its industrial belt. The management of the ecclesiastic estates in the district of Lleida (El Segrià) was far from what could be defined as modern agriculture to facilitate the development of the territory, and at a crucial moment of Catalan history. We can find the root of the problem in the lack of renewal of farming practices that remained unchanged over time, as well as a historical context in which there was an absence of projects for renewal, and not only on the ecclesiastic estates. Private projects linked to the Urgell Canal also employed very conservative practices conceptually distant from commercial agriculture. This is a new view that presents a less dynamic Catalonia and one that, thus, moves away from the dominant paradigm of an innovative Catalan rural world dedicated to specialisation for the market. ${ }^{7}$

The ecclesiastic estates referred to are Astó, Vinatesa, Els Olomins, Moredilla and La Cogullada in the eastern part of the municipality of Lleida, Safareig and Gatén, in the municipality of Bellvís, and Raimat and Sucs in the western part of Lleida. There is also Montagut, in the municipality of Alcarràs. The latter will be the subject of a more detailed study, as it was the one of the most intensively and extensively farmed areas from the 18th century on. The first seven were dry land areas until they began to be irrigated from the Urgell Canal in the 1860s. Montagut was partially irrigated by the Pinyana irrigation ditch throughout the period under study. From the 1910s on, the waters of the Aragon and Catalonia Canal arrived and these also irrigated the municipalities of Raimat and Sucs.

Why did the management of the ecclesiastic estates in the Lleida area hinder the agrarian development of western Catalonia plains? To answer this question adequately, it is first necessary to analyse their management at the end of the seigniorial period (1780-1850) and their adaptation to the historical and technological context. Then secondly, we must look at the following stage (1850-1960) during which the rural world entered a general capitalist development. Here we must ask whether the new owners of the seigniorial estates managed them in a way that encouraged such reforms as incorporating necessary new inputs (like mineral and chemical fertilisers) to an area with poor or, at the most, moderately productive, land, in a context of an organically-based economy, or if they promoted alternative crops to generate higher remuneration and allow an improvement in the peasants' living conditions.

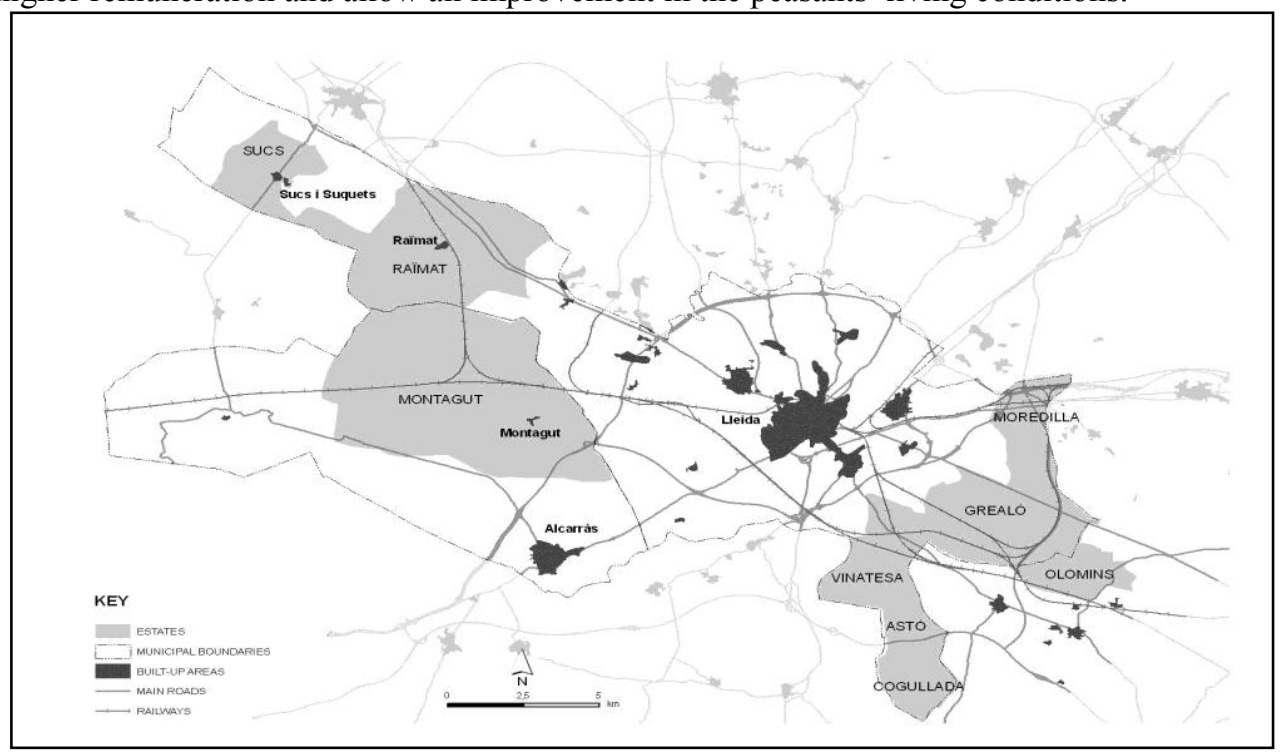

Map 1. Location of the estates studied

\footnotetext{
7 The irrigation from the Urgell Canal was mainly aimed at guaranteeing the harvets of the Mediterranean trilogy, limiting the market gardens per exploitation. Only alfalfa grew significantly between 1880 and 1920.
} 


\section{The management of the ecclesiastic estates at the end of the seigniorial period and the impact of the disentailment and the liberal agrarian reform (1780-1850)}

Astó, Vinatesa, Els Olomins, Moredilla, La Cogullada, Safareig, Gatén and Montagut belonged to the Chapter of the Canons and Dean of the Cathedral of Lleida; Raimat and Sucs were owned by the Pia Almoina, administered by the same chapter. With the Disentailments of Mendizábal in 1836 (which affected ecclesiastic possessions and those of the military orders) and Madoz in 1855 (related to municipal properties and those of such institutions as the Pia Almoina, an charity institution from the Old Regime) there were changes of ownership, with most of these estates being privatised. Montagut was considered exempt from confiscation on the basis of the property deeds the chapter presented. ${ }^{8}$

All these areas were part of a wider economic system: transhumance. ${ }^{9}$ From their summer pastures in the Pyrenees, some of the shepherds spent the winters in the Catalan Central Depression (the Lleida region) and paid tithes to the lords of these municipalities. In El Segrià, the Lleida district, this was mainly (through ownership or administration) to the Lleida Chapter. They paid a tithe of three quarters of a sixteenth of the sheep, which the chapter immediately sold at the going price to the owners of the flocks. These shepherds were mainly from the northern districts of Catalonia, in the Pyrenees, although there were also, but less frequently, shepherds from the Lleida area.

The ecclesiastical estates of the Lleida district are among the winter pastures. These rural areas had not been settled in modern times. Little worked in the $17^{\text {th }}$ century, farming spread in the 1730s and then especially in the second half of the $18^{\text {th }}$ century, although this was variable. There was an increase in the farmed area in Montagut and Grealó that reflected the rise in revenue collection (a tithe plus shares of fruit for the transfer of the land), while there was very limited growth in framing in the other municipalities. Table 3 reflects this evolution. Although it only shows the data for wheat, most years there was a minor production of barley and a practically irrelevant quantity of oats.

Table 3. Tithes and income from the land generated in various ecclesiastical estates. Quarteres of wheat of 73.36 litres

\begin{tabular}{cccccccccccc}
\hline \multicolumn{10}{c}{} & \multicolumn{10}{c}{$\begin{array}{c}\text { Vinatesa } \\
\text { and } \\
\end{array}$} & Montagut & Raimat & Sucs & Astor & Cogullada & Olomins & Moredilla & Grealó & Sedaó & Sample \\
\hline $1731-1740$ & 174.6 & 10.4 & 40.2 & 55.8 & 128.4 & 36.2 & 16.5 & 125.6 & 16.7 & 604.4 \\
$1741-1750$ & 242.8 & 42.7 & 40.0 & 16.3 & 109.5 & 35.6 & 21.9 & 88.2 & 14.7 & 611.7 \\
$1751-1760$ & 316.3 & 33.4 & 12.5 & 26.6 & 117.8 & 56.5 & 49.6 & 109.8 & 25.5 & 748.0 \\
$1761-1770$ & 346.3 & 119.5 & 70.4 & 66.5 & 167.8 & 61.9 & 68.2 & 256.0 & 22.0 & $1,178.6$ \\
$1771-1780$ & 445.6 & 251.0 & 215.2 & 53.7 & 211.2 & 94.7 & 122.6 & 302.5 & 31.4 & $1,727.9$ \\
$1781-1790$ & 823.4 & 456.9 & 345.7 & 60.2 & 227.6 & 89.3 & 117.6 & 285.4 & 39.9 & $2,446.0$ \\
$1791-1800$ & 910.9 & 448.8 & 325.0 & 41.8 & 250.8 & 126.4 & 143.1 & 295.1 & 61.2 & $2,603.1$ \\
\hline
\end{tabular}

Source: Llibres d'Exàmens, Arxiu Capitular de Lleida.

Let us analyse Montagut in detail. In 1808-1810, there was a large area leased to settlers. If the total cultivated area is analysed according to the distribution, we can see that most of the plots in both the dry-land area and the area irrigated from the Pinyana irrigation ditch were small, with at the most seven hectares, which was mainly dry land. It can also be seen there was a significant number of plots of dry lands between 10 and 18 ha. These larger areas must surely have combined arable farming with livestock. ${ }^{10}$

\footnotetext{
8 "Secretaría de la Junta de Admón. y Venta de Bienes del Clero Secular, Lleida, 19 de marzo de 1844", Fondo Desamortización. Arxiu Històric de Lleida.

9 There is a map of trashumance in Catalonia in

http://web.udl.es/dept/historia/Agraria/Transhumance\%20in\%20Catalonia.pdf

Vicedo-Rius, E., J. Boixadera, J.R.Olarieta and J.M. Martínez (2008). "Las transformaciones territoriales del área rural de Lleida, 1750-1950", in Garrabou, R. and J.M. Naredo (ed.), El paisaje en perspectiva histórica. Formación y transformación del paisaje en el mundo mediterráneo, pp. 163-186. Spain, Zaragoza: Prensas Universitarias de Zaragoza. Co-edition with the Sociedad Española de Historia Agraria.
} 


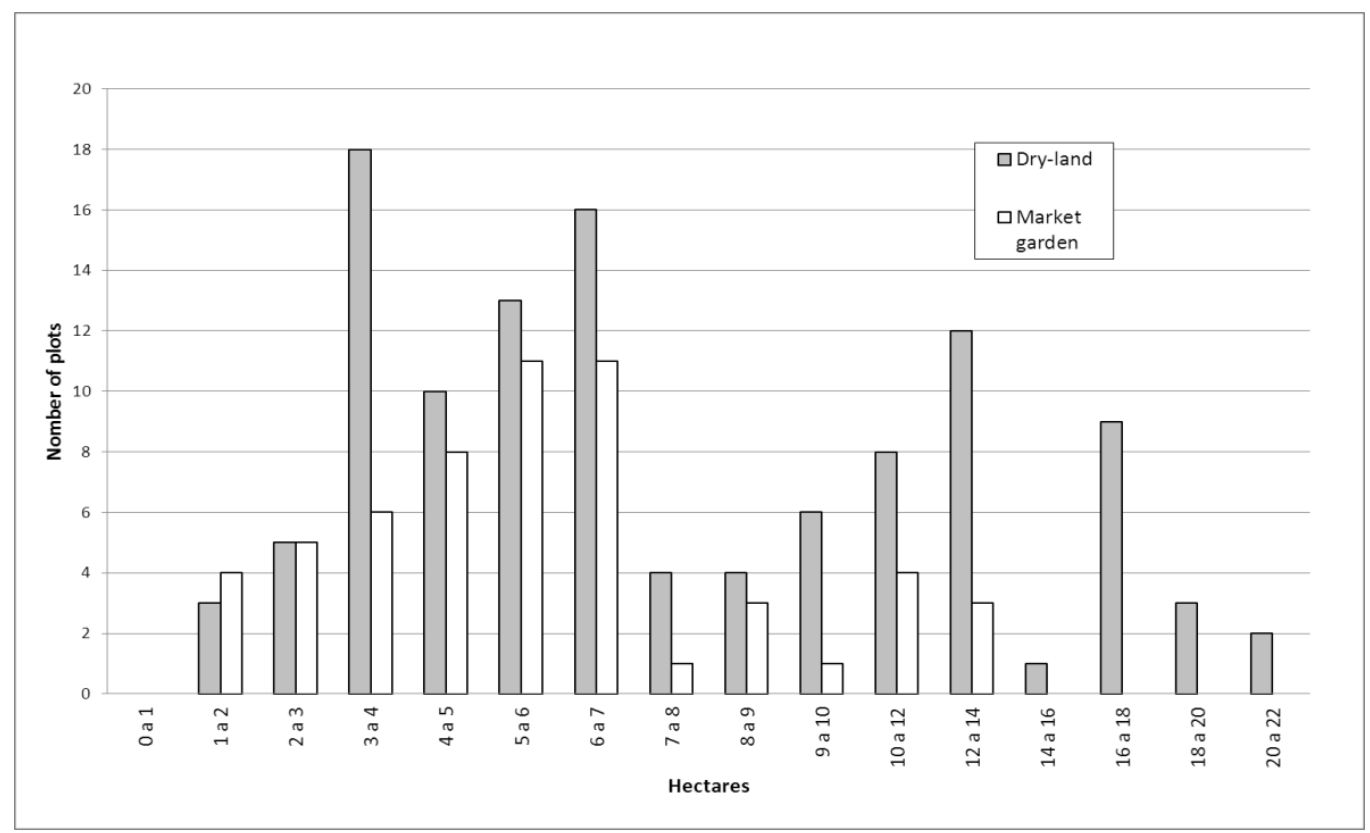

Graph 1. Structure of land distribution in Montagut, 1808-1810

Source: "Licencias para cultivar en terrenos del Cabildo. S. XVIII-XIX", in R.14. Vàries notes, y borradors que contenen Resumen de..., Arxiu Capitular de Lleida.

These lands were farmed under licences to farm, a sharecropping contracts that could be rescinded at any moment without any rights for the sharecropper. The structure of the licensed farms in Montagut (table 4) was characterised by a significant number of farmers with concessions of up to 10 ha (94 in total, of whom 39 had 5 ha or less and 55 between 5 and 10 ha) out of a total of 138. More than a quarter of the farmers (43 out of 138) had concessions between 10 and 25 ha. The average area per sharecropper was a moderate 9.21 ha, that was less in the first two periods (3.47 and 7.10 respectively).

Lleida and Alcarràs stand out among the hometowns of the sharecroppers, with the people holding the majority of the land, especially the irrigated areas. The people from Alcarràs had the greater part of the irrigated land, while those from Lleida held most of the dry-land areas. The 1,270.31 ha ceded were 27.2 per cent of the total area of 4,668.37 ha. Starting from the basis that the farmers with licences for Montagut had property in their places of residence, the extra lands farmed in Montagut must have played an important role in the reproduction of many peasant family units. However, there was an initial handicap: the contract could be terminated at any moment with or without justification.

Table 4. Structure of the working of the land by type of land and place of residence. Montagut, 1808-1810.

\begin{tabular}{|c|c|c|c|c|c|c|c|c|}
\hline \multirow[b]{3}{*}{ ha } & \multicolumn{4}{|c|}{ Lleida } & \multicolumn{4}{|c|}{ Alcarràs } \\
\hline & $\mathrm{n}^{\mathrm{o}}$ & irrigate & & & $\mathrm{n}^{\mathrm{o}}$ & & & \\
\hline & $\begin{array}{c}\text { sharecropper } \\
\text { S }\end{array}$ & $\begin{array}{c}\mathrm{d} \\
\text { ha }\end{array}$ & $\begin{array}{c}\text { dry land } \\
\text { ha }\end{array}$ & $\begin{array}{l}\text { total } \\
\text { ha }\end{array}$ & $\begin{array}{c}\text { sharecropp } \\
\text { ers }\end{array}$ & $\begin{array}{l}\text { irrigated } \\
\text { ha }\end{array}$ & $\begin{array}{c}\text { dry land } \\
\text { ha }\end{array}$ & $\begin{array}{l}\text { total } \\
\text { ha }\end{array}$ \\
\hline $0-5$ & 15 & 3.93 & 44.98 & 48.91 & 14 & 41.05 & 5.24 & 46.29 \\
\hline $5-10$ & 19 & 13.97 & 126.64 & 140.61 & 24 & 107.86 & 6201 & 169.87 \\
\hline $10-15$ & 6 & 6.99 & 64.19 & 71.18 & 6 & 37.56 & 35.81 & 73.37 \\
\hline $15-20$ & 7 & 2.62 & 118.34 & 120.96 & 2 & 6.55 & 30.57 & 37.12 \\
\hline $20-25$ & 9 & 53.71 & 141.05 & 194.76 & 3 & 31.44 & 32.31 & 63.75 \\
\hline $25-30$ & 1 & 8.73 & 19.65 & 28.38 & & & & \\
\hline Total & 57 & 89.95 & 514.85 & 604.80 & 49 & 224.46 & 165.94 & 390.4 \\
\hline
\end{tabular}




\begin{tabular}{|c|c|c|c|c|c|c|c|c|c|}
\hline & & ther place & & & & & otal & & \\
\hline ha & $\mathrm{n}^{\mathrm{o}}$ sharecroppers & $\begin{array}{l}\text { irrigated } \\
\text { ha }\end{array}$ & $\begin{array}{c}\text { dry land } \\
\text { ha }\end{array}$ & $\begin{array}{l}\text { total } \\
\text { ha }\end{array}$ & $\mathrm{n}^{\mathrm{o}}$ sharecroppers & $\begin{array}{l}\text { irrigated } \\
\text { ha }\end{array}$ & $\begin{array}{c}\text { dry land } \\
\text { ha }\end{array}$ & $\begin{array}{l}\text { total } \\
\text { ha }\end{array}$ & ha/shcrp \\
\hline $0-5$ & 10 & & 40.18 & 40.18 & 39 & 44.98 & 90.40 & 135.38 & 3.47 \\
\hline $5-10$ & 12 & & 79.91 & 79.91 & 55 & 121.83 & 268.56 & 390.39 & 7.10 \\
\hline $10-15$ & 6 & & 76.42 & 76.42 & 18 & 44.55 & 176.42 & 220.97 & 12.28 \\
\hline $15-20$ & 2 & & 35.37 & 35.37 & 11 & 9.17 & 184.28 & 193.45 & 17.59 \\
\hline $20-25$ & 2 & 21.4 & 21.83 & 43.23 & 14 & 106.55 & 195.19 & 301.74 & 21.55 \\
\hline $25-30$ & & & & & 1 & 8.73 & 19.65 & 28.38 & 28.38 \\
\hline Total & 32 & 21.4 & 253.71 & 275.11 & 138 & 335.81 & 934.50 & 1.270 .31 & 9.21 \\
\hline
\end{tabular}

Source: Licencias para cultivar en terrenos del Cabildo. S. XVIII-XIX, in R.14. Vàries notes, y borradors que contenen Resumen de..., Arxiu Capitular de Lleida.

Let us analyse now the origins of the incomes generated by the Montagut estate. To facilitate this analysis, the non-decimal incomes that the Chapter of Cannons and Dean of Lleida Cathedral obtained are used. These consisted of a third ["terç"] of the lease of grass, the lease of manure and the cereals of the "terratge". This varied between an eleventh and a twelfth. The other two thirds of these incomes were received by another administration, that of "Aniversaris Majors". Thus, graph 2 reflects the evolution of the income from the land received directly by the Chapter Mensa of Lleida Cathedral, that is, a third of the total generated.

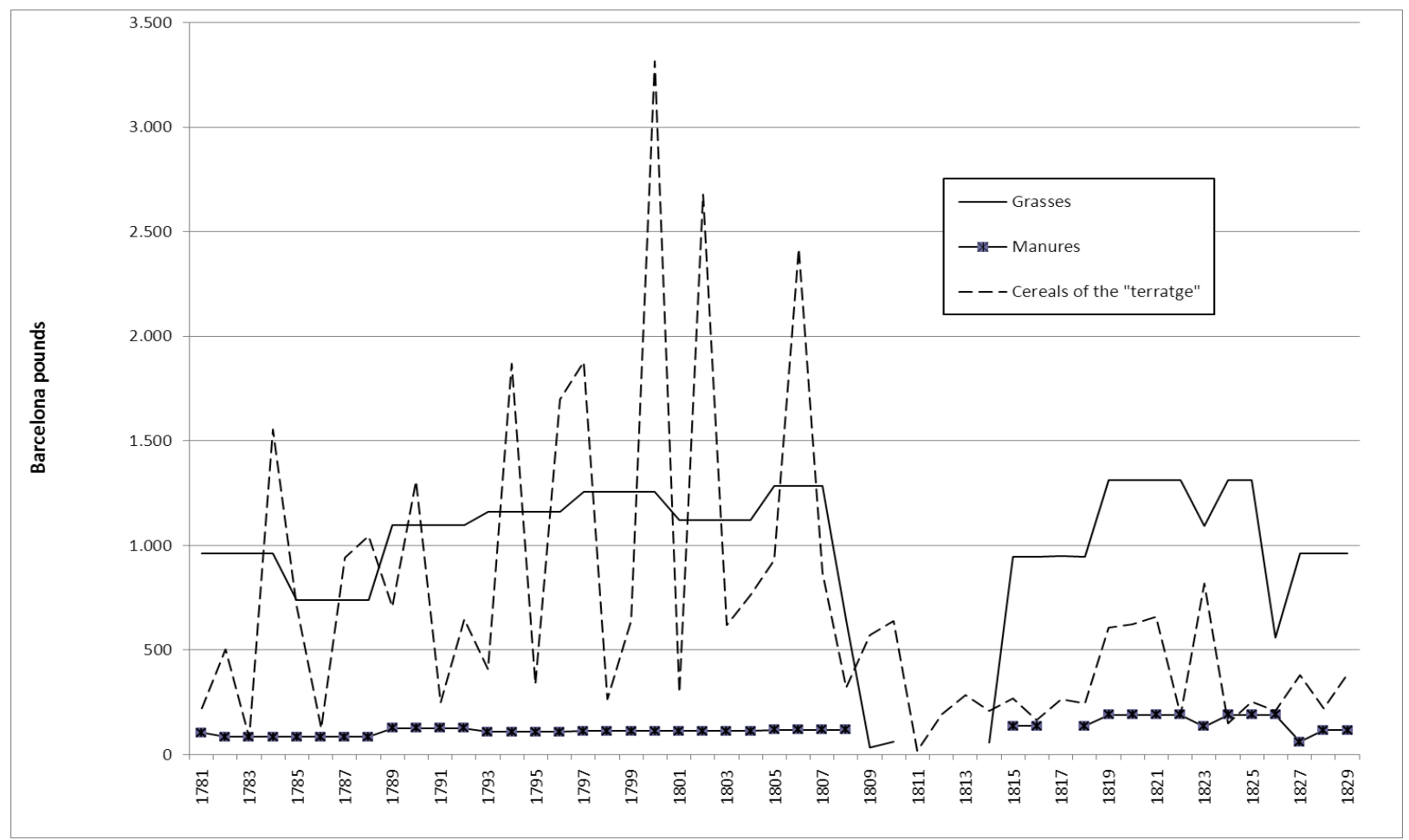

Graph 2. Income from the land in Montagut received by the Chapter of Lleida, 1781-1829

Source: "Comptes de la Administració del Ters del terme Rural de Montagut...". Caja P4B_M3_P1_C04, Arxiu Capitular de Lleida. The data for the "terratge" are from the Llibres d'Exàmens. The "Comptes" refer back to these. Data in appendix 1. http://web.udl.es/dept/historia/Agraria/Appendix\%201\%20\%26\%202.pdf

Until 1807, the lease of grazing was very stable and generally more than a thousand pounds a year. After the Napoleonic Wars (1808-1814), from 1815 the incomes from leasing grazing land for transhumance returned to pre-war levels. Something similar happened with the leasing of manures, but with a much lower annual income. The change came with the income from the "terratge". The decrease was due to a double factor: the fall in prices during the first third of the $19^{\text {th }}$ century and drop in production when compared with the last third of the $18^{\text {th }}$ century (graph 3 ). The level of income from the leasing of grazing and manure increased very significantly in relative terms if compared with the incomes from 
the third of the "terratge".

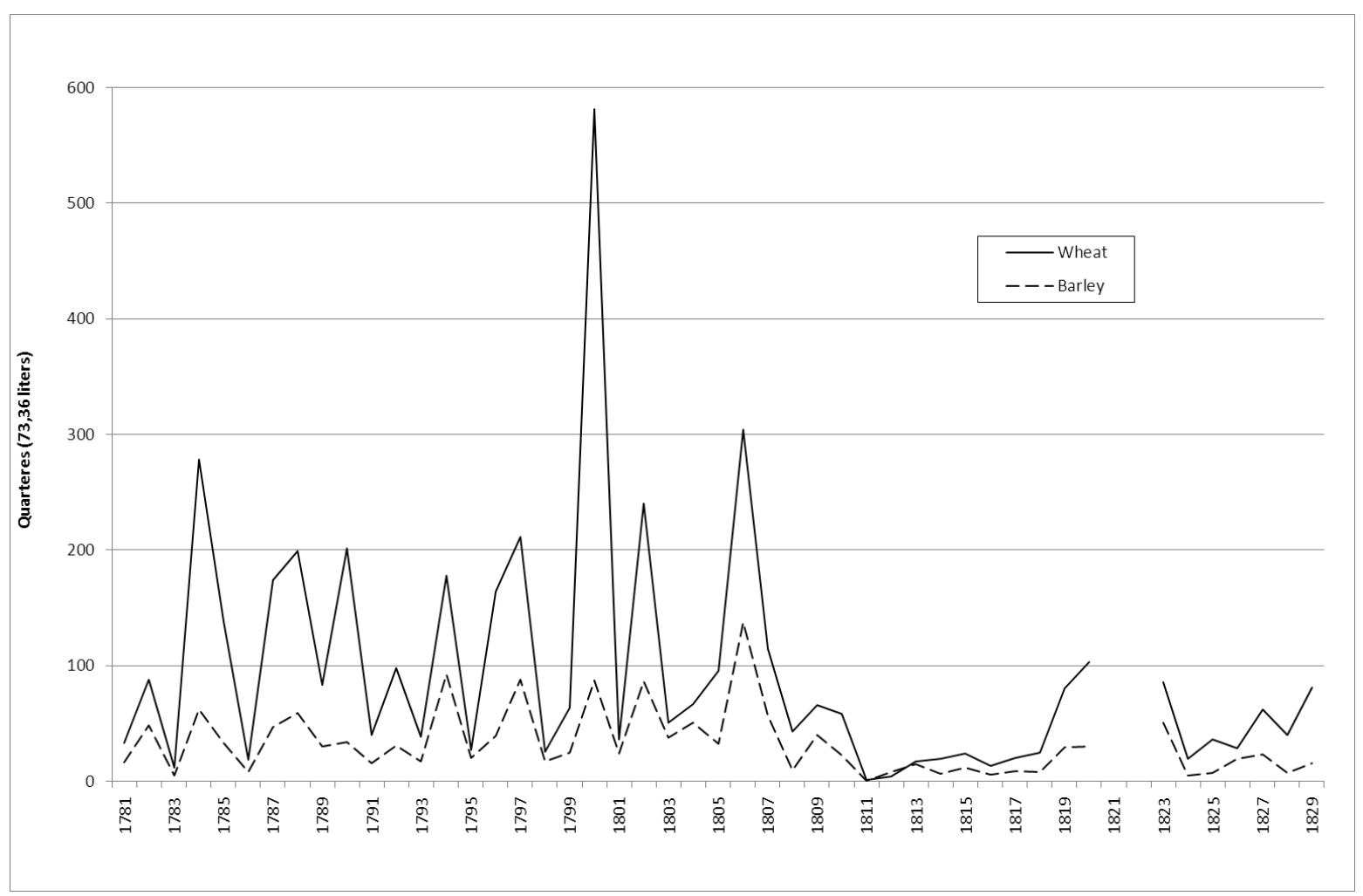

Graph 3. Wheat and barley from the third of the "terratge", 1781-1829.

Source: Llibres d'Exàmens, 1781-1829, Arxiu Capitular de Lleida. Data in appendix 2. http://web.udl.es/dept/historia/Agraria/Appendix\%201\%20\%26\%202.pdf

Graph 3 shows the quantities produced and collected for the third of Montagut. From 1807 on, the values fell below the levels from the earlier period. The series stopped in 1829. We can consider a working hypothesis that from 1808 on, the situation firstly of the war with France and then periods of liberal reform and absolutist counter-reform, and in a context where the ownership of the Chapter's estates was questioned, hindered the continuity of a model of temporary leases of land. Finally, with the disentailment of Mendizábal, the chapter would only conserve ownership of the Montagut estate, the rest of the lands being taken over by the Administration of National Goods. In 1843-1844, they were ready for auction.

\subsection{The impact of disentailment and the liberal agrarian reform}

Ramon Garrabou has shown that, as in other capitalist countries, the Spanish liberal agrarian reform was mainly focussed on abolishing the old institutional framework, consolidating the rights to private property and generating conditions for the normal working of a market economy. ${ }^{11}$ In this and other studies from his wide bibliography, he questions the theory of the backwardness of Spanish agriculture.

"However, in our opinion, the little scope of the structural reform policies and the insufficiencies observed in aspects of agrarian policy should not be interpreted as one of the symptoms of a supposed backwardness or a of the behaviour that the agrarian bourgeoisie are supposed to display, but rather the complete opposite. They are expression of their particular interests, which obviously do not coincide with the rest of society. In this sense, questioning the paradigm of backwardness does not necessarily mean sustaining that the rural world reached the

\footnotetext{
11 "Sin embargo, la escasa entidad de las políticas de reforma estructural y las insuficiencias observadas en otros planos de la política agraria, en nuestra opinión, no deben interpretarse como una de las manifestaciones de un supuesto atraso o desviación del comportamiento que se supone a una burguesía agraria, sino todo lo contrario. Son la expresión de sus intereses particulares, que obviamente no son coincidentes con los del resto de la sociedad. En este sentido, cuestionar el paradigma del atraso no ha de comportar necesariamente sostener que el mundo rural alcanzó los niveles máximos de desarrollo, sino simplemente evidenciar, por un lado, que llegó hasta donde le permitían las exigencias del sistema capitalista y, por otro, y más importante aún, que existían otras alternativas, si se hubieran llevado a cabo reformas estructurales que hubieran significado niveles semejantes o superiores de producción y, al mismo tiempo, mejoras de los ingresos del campesinado pobre". Garrabou, R., "Crecimiento agrario, atraso y marco institucional", in A.A.V.V. (2001). El pozo de todos los males. Sobre el atraso en la agricultura española contemporánea, pp. 215-243. Spain, Barcelona: Crítica.
} 
highest levels of development. It rather simply shows, on one hand, that it reached as far as the demands of the capitalist system allowed it and, on the other, and more importantly, that there were alternatives if structural reforms had been carried out that would have meant similar or higher levels of production and, at the same time, improvements in the income of the poor peasantry" (p. 243)

The expropriation and sale of the church's goods was not a requirement for consolidating a new institutional framework. It responded, on one hand, to the financial needs of the Spanish exchequer and, on the other, to reducing the economic power of the church and favouring the purchasers (the bourgeoisie and the aristocracy, who would accept this new framework.

On the western Catalan plain, as well as the expropriating and auctioning of small ecclesiastical properties, generally belonging to rural parishes, we must add the expropriation and sale of the large ecclesiastical estates. The preparatory documentation for the auction shows us that, except for the Safareig and Gatén estates in Bellvís near Lleida whose lands were shared out among a large number of sharecroppers with licenses to farm from Bellvís, a great part of the other lands (Grealó, Moredilla, Vinatesa, La Cogullada and Astó) was difficult to farm but apt for use as pasture for transhumance livestock. There is no list of sharecroppers, which indicates that the cultivable areas must not have been worked, or only occasionally so.

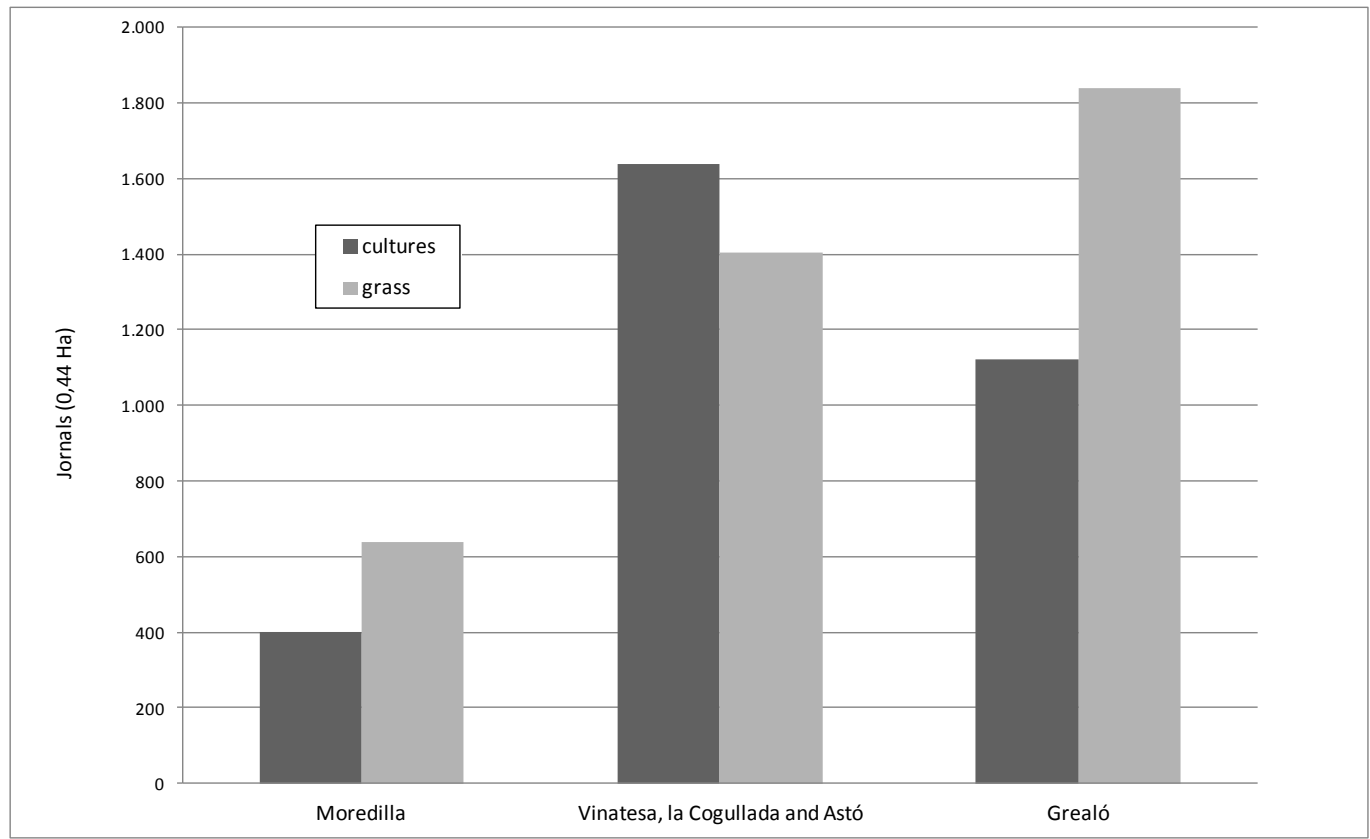

Graph 4. Uses of the land according to its potentialities, 1843-1844

Moredilla, Vinatesa, La Cogullada, Astó and Grealó

Source: "Expedientes de tasación, Pliego 1843-1844”, Fondo Desamortización, HD25, Arxiu Històric de Lleida.

Various Spanish authors were favourable to sharing out the lands of the large estates in Castile, Extremadura and Andalusia among the peasantry with little or no land of their own. In 1836, Álvaro Flórez Estrada, a Spanish economist and politician, defended this sharing on the basis of the emphyteutic contract: ${ }^{12}$

With the emphyteutic system all the families of the proletarian class would be the holders of the useful domain of the land they worked and, consequently, interested in supporting the reforms and the throne of Isabel, as they would see

12 Despite its feudal origins, the emphyteutic contract was not abolished in the liberal reform agrarian and was compared with a contract between peers. This was a long-term contract, often in perpetuity in Catalonia, as long as a dues were paid, often part of the fruit- to the holder of the direct domain. The leaseholder received the useful domain, which he could pawn or sell. In this latter case, the purchaser paid a right to the owner of the direct domain. Many of the owners of small and medium sized properties in Catalonia were, in fact, leaseholders. The redemption of the emphyteusis accelerated after 1945 with the new legislation. Serra, E. (1983), "Notes sobre els orígens ..." Sebastià, E. and Piqueras, J. A. (1987), Pervivencias feudales y revolución democrática. Spain, Valencia: Edicions Alfons el Magnànim. Mirambell, A. (1997), Els censos en el dret civil de Catalunya: la qüestió de l'emfiteusi (a propòsit de la Llei especial 6/1990). Spain, Barcelona: Generalitat de Catalunya. Departament de Justícia. 
their welfare in these figures. To the contrary, the system of selling the estates would make the fate of this numerous class even more wretched than it currently is, and thus, would make them hate all reforms and the existing order of things. $^{13}$

Similar arguments arose in western Catalonia. José Castel, director of the Sociedad Económica de Amigos del País (Economic Society of Friends of the Country) in Lleida, responded to an official survey about agricultural credit on the $11^{\text {th }}$ of June 1852. When answering the first question about ownership, he stated:

"In the province the owners very generally farm their lands (...). Despite this generality, at a circumference of four leagues from this City there are more than a hundred thousand aranzadas ${ }^{14}$ of land that belong to Beneficence, Ecclesiastical Corporations, or Lay Lords that are not divided up into properties; and thus are mainly farmed by settlers, or barren for natural pastures and livestock. This is a very serious harm because it makes a large part of those lands unproductive, or that they produce less than half of what they would give reduced to private property. From this indivisibility, another very considerable prejudice arises. In the City of Lleida alone, there are six hundred day labourers who have no property and thus remain unemployed on the days when they fail to find a wage. This wrong would be cut down by dividing those extensive territories into properties ".15

And in the second answer, he wrote:

"The properties are very divided in this province to such an extent that in irrigated ones, there are many of one, two or three aranzadas of land, and very few that reach twenty. But the dry lands are bigger; but there are very few that reach a hundred aranzadas".

The estates of the Chapter of Lleida, except for Montagut, which they kept hold of, had an unexpected fate. Instead of being sold at public auction, the state awarded them to Beneficiaries of Lleida Cathedral as compensation for having auctioned off all their properties, which the courts finally considered could not be expropriated. In other words, Vinatesa, La Cogullada, Astó, Moredilla and Grealó in Lleida, and Safareig and Gatén in Bellvís passed from the chapter to the state and then became the private property of what would later be known as the Unión Laical de Beneficiados (Lay Union of Beneficiaries) (Vicedo-Rius, 2009).

Neither the ownership of the ecclesiastic estates, nor of the beneficence, were shared, even partially, among the numerous landless peasantry or those with small properties. Despite the general use, of the emphyteutic contract since the Middle Ages media in Catalonia as a whole, also in the western plains (Serra, 1983), and having applied it to various lords in the framework of the agrarian colonisation process during the second half of the $18^{\text {th }}$ century ${ }^{16}$, there was no distribution of land in either western Catalonia or any other areas of large landownership in southern Spain in the context of the disentailment ${ }^{17}$.

How were the Chapter and Beneficiaries' estates managed in the new society and economy after the mid $19^{\text {th }}$ century? Montagut is still a good for example to analyse.

\section{Property, Contracting and Agrarian Development (1850-1960).}

In 1904, Josep Bayer y Bosch, an industrial engineer, assessor to the General Irrigation Syndicate of the Canal d'Urgell, stated that

\footnotetext{
13 Con el sistema enfitéutico todas las familias de la clase proletaria serían dueñas del dominio útil de la tierra que cultivasen y, por consiguiente, interesadas en sostener las reformas y el trono de Isabel, pues en ellas verían cifrado su bienestar. Por el contrario, el sistema de vender las fincas hará la suerte de esta numerosa clase más desgraciada de lo que es aún en la actualidad, y por consiguiente, les hará odiosa toda reforma y el orden existente de cosas. Flórez Estrada, A. (1836), "Del uso que debe hacerse de los bienes nacionales", p. 363.

${ }_{14}$ Aranzada is used as a synonym for jornal in Lleida.

15 "En esta provincia los propietarios cultivan generalísimamente sus tierras (...). No obstante esta generalidad, a cuatro leguas de circunferencia de esta Ciudad hay más de cien mil aranzadas ${ }^{15}$ de tierra perteneciente a Beneficencia, Corporaciones Eclesiásticas, o Señores Laicos que no están divididas en propiedad; y por consiguiente cultivadas su mayor parte por colonos, o yermos para pastos naturales o ganado. Esto es un mal gravísimo porque hace improductivas gran parte de aquellas tierras, o que por lo menos no producen la mitad de lo que rendirían reducidas a propiedad particular. De esta indivisión resulta otro perjuicio muy considerable. Acaso solo en la Ciudad de Lérida hay seiscientos jornaleros que no tienen ninguna propiedad y por consiguiente quedan sin ocupación los días que no encuentran jornal. Este mal se cortaría dividiendo en propiedades aquellos dilatados territorios". "Las propiedades están muy divididas en esta provincia en tanto grado que en regadío hay muchas de una, dos y tres aranzadas de tierra, y muy pocas que lleguen a veinte. Pero los secanos son de más extensión; pero son rarísimas las que lleguen a cien aranzadas". "Informe del Director de la Sociedad Económica de Lérida sobre el crédito territorial", in Preguntas realizadas por el Ministerio de Fomento a las Juntas de Agricultura y Sociedades Económicas..., Bancos agrícolas, bundle 123, Archivo del Ministerio de Agricultura.

16 "Propietat, formes d'accés a la terra i distribució dels ingressos", in Vicedo-Rius, E. (1991). Les terres de Lleida ..., 4, $216-314$.

17 "Desamortización y despojo de los campesinos", in "Cap. 8. Apogeo del liberalismo autoritario, 1854-1863", Fontana, J. (2007). La época del liberalismo, pp. 277-282, volume 6 of Fontana, J. and R. Villares (directors), Historia de España. Spain, Barcelona-Madrid: Crítica-Marcial Pons.
} 
“in these plains of the Lower Urgell, near Lérida [Lleida], where the waters of the Canal [d'Urgell] have flowed for forty years, despite which, almost everything is uncultivated, in the same way as the large estates of the southern Peninsula".

And added,

"And these terrains, that are neither arid nor unproductive, crossed by irrigation channels, could not only be settled to give healthy homes to thousands of land-working families that nowadays live in these hovels that line the tortuous and very narrow alleys of the city [Lleida], in perhaps worse conditions than the gypsies of the Sacro-Monte [in Andalusia]. ",18

As well as showing the difficulties that arise when the a new irrigation canal is opened, the above text shows one of the social problems that characterised the city of Lleida from the $18^{\text {th }}$ century. This became even more acute in the second third of the $19^{\text {th }}$ century during the liberal agrarian reform: large numbers of landless peasants or without enough land to guarantee social and economic continuity.

We know that the lands of the ecclesiastical estates were not distributed among the landless peasantry or those with little land. Despite this, farming licences continued to be conceded in the rural possessions of both the Beneficiaries and in Montagut owned by the Chapter. Analysing the licences to farm Montagut from 1808-10 to 1964 will allow the management of, and the changes to these lands to be defined and the repercussions of these on economic growth to be evaluated in detail. This section has four aims. The first is to analyse the kind of farming practices that the licences reveal and whether these were adequate in the technical-economic context of the stage. The second step is to evaluate if the farming contracts were adequate to the agro-ecological context and balanced enough to satisfy the expectations of income for the ownership and of earning a living by the sharecroppers, with limited risk. Thirdly, we analyse how the lands of the beneficiaries were worked. The fourth aspect is to study whether processes of colonising large estates more in line with modern agriculture were designed and materialised on the western Catalan plain in the same period.

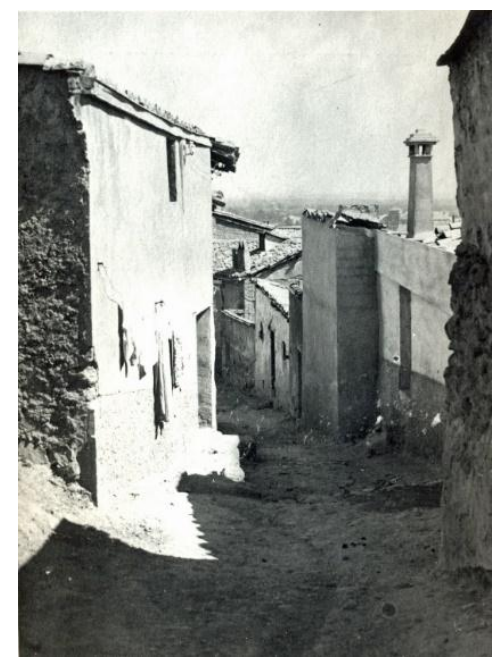

The Canyeret neighbourhood, in Lleida, where the poorest peasants lived crowded together at the beginning of the 20th century. Source: Servicio de Audiovisuales, Institut d'Estudis Ilerdencs, Lleida.

\subsection{The Agrarian Practices according to the Farming Licences}

Various studies into contracting in western Catalonia have shown that, in general, only certain practices that the owner demanded were detailed. For all other farming activities (those that any good farmer knew and applied), it was only indicated that the land had to be worked "in the use and practice of a good farmer". The farming licences also included this sentence. Allen \& Lueck (2002) have highlighted that the simplicity of the contracts depended on the costs of enforcing them. Contemporary farming licences tend to be long, although when their clauses refer to agronomic

\footnotetext{
18 “en esas llanuras del Bajo Urgel, próximas a Lérida [Lleida], por las que corren hace cuarenta años las aguas del Canal [de Urgel], a pesar de lo cual casi todo está inculto, a modo de los latifundios de la región del Mediodía [peninsular]" "Y esos terrenos, que no son áridos ni improductivos, surcados por acequias de riego, no solo podrían colonizarse para proporcionar habitación sana a miles de familias agrícolas que hoy viven en esas covachuelas que forma los tortuosos y angostísimos callejones de la ciudad [Lleida], en peores condiciones quizás que los gitanos del Sacro-Monte [en Andalucía]”. Bayer y Bosch, J. (1904), El latifundio ante el problema agrario y solución en comarcas despobladas, p. 129. Spain, Lleida: Sol i Benet. The observations between brackets are by the author of this article.
} 
questions they are more closely related to traditional practices than with encouraging new inputs, crops or techniques.

Garrabou, Planas, \& Saguer (2001b) have shown, the crisis at the end of the $19^{\text {th }}$ century in Catalonia, with falling prices and rising wages, meant that the consolidation of classic capitalist exploitations, based on owners of the land and paid employees became unviable. This led to the spread of such agrarian contracts as sharecropping, which allowed a good part of the production costs to be transferred to the lease-holding peasantry. In the case of sharecroppers (farmers with licences) in Montagut, the novelty consisted of the requirement to carry out works to prepare the land for farming, with the saving in wages that this meant for the owner ${ }^{19}$. From the mid $19^{\text {th }}$ century, the farmer was progressively obliged to level the plots, build and improve the verges, fill in gullies, and, on the land that could be irrigated, dig and maintain ditches for the irrigation water and drainage. In the second decade of the $20^{\text {th }}$ century, the waters of the Aragon and Catalonia Canal reached Montagut, and were added to those from the Pinyana irrigation ditch. ${ }^{20}$

The licences from 1909 and 1922 indicated that permission was required to grow hemp, maize and beet. Those from 1958 this stipulated permission for growing hemp and rice. In all of these, growing grapevines and fruit trees needed a special contract. In both 1922 and 1958, it was stipulated that a sixth of the land in La Horta Vella and the estate of La Clamor had to be sown with alfalfa.

The above-mentioned clauses of the contracts did not include any obligation regarding crop rotation or the use of mineral and chemical fertilisers, nor was there any obligation to incorporate new crops, except alfalfa in the rural estates mentioned above.

Table 5. Income obtained from Montagut by the Chapter of Lleida, 1856-1875

\begin{tabular}{|c|c|c|c|c|c|c|c|c|c|c|}
\hline & 1856 & & 1860 & & 1863 & & 1872 & & 1875 & \\
\hline & $\begin{array}{c}\text { Quarteres } \\
\text { (73.36 } \\
\text { litres) } \\
\text { (Q) }\end{array}$ & $\begin{array}{c}\text { Rals } \\
\text { (R) }\end{array}$ & Q & $\mathrm{R}$ & Q & $\mathrm{R}$ & Q & $\mathrm{R}$ & Q & $\mathrm{R}$ \\
\hline Wheat & $1,029.0$ & $29,140.0$ & 613.0 & $47,328.0$ & 971.0 & $67,036.0$ & $2,639.3$ & $172,870.9$ & 1.095 .8 & $63,553.5$ \\
\hline Barley & 579.0 & $22,431.0$ & 376.0 & $13,476.0$ & 366.5 & $12,018.8$ & $1,014.5$ & $22,826.3$ & 595.8 & $16,681.0$ \\
\hline Mixture, mainly of barley & 72.0 & $4,320.0$ & 11.8 & 658.0 & & & & & & \\
\hline Oats & 27.3 & 599.5 & 6.8 & 229.5 & 10.0 & 280.0 & & & & \\
\hline Rye & 4.0 & 176.0 & & & & & & & & \\
\hline Foxtail millet & & & 3.8 & 157.5 & 6.3 & 237.5 & 8.0 & 296.0 & 5.5 & 192.5 \\
\hline Legumes & 3.0 & 156.0 & & & & & & & & \\
\hline Beans & 2.0 & 188.0 & 2.3 & 202.5 & 1.0 & 76.0 & 1.8 & 129.5 & 1.0 & 88.0 \\
\hline Broad beans & & & 2.8 & 123.8 & 1.5 & 60.0 & & & & \\
\hline Grapes & & $1,142.0$ & & & & $1,312.0$ & & $2,254.0$ & & $1,797.0$ \\
\hline Potatoes & & & & & & 94.0 & & 337.0 & & 286.0 \\
\hline Hemp & & & & & & & & & & 38.0 \\
\hline Hemp and seed & & & & & & 42.0 & & & & \\
\hline Potatoes and hemp & & 112.0 & & & & & & & & \\
\hline Saltwort & & & & & & 36.0 & & & & \\
\hline $\begin{array}{l}\text { Lesser fruits, } \\
\text { grapes, saltwort, } \\
\text { potatoes, oil and hemp }\end{array}$ & & & & $1,253.0$ & & & & & & \\
\hline Oil & & 15.0 & & & & 23.0 & & 28.0 & & 131.0 \\
\hline Alfalfa & & & & & & & & 38.0 & & 103.0 \\
\hline Beehives & & & & & & 64.0 & & & & \\
\hline "damage caused & & & & & & & & & & \\
\hline by shepherds" & & & & & & 32.0 & & & & 137.0 \\
\hline Bulrushes & & & & & & 36.4 & & & & \\
\hline Gross income & & $110,875.5$ & & $63,428.3$ & & $81,347.7$ & & $198,779.6$ & & $83,007.0$ \\
\hline
\end{tabular}

\footnotetext{
19 The licence to farm Montagut (1922). can be seen in http://web.udl.es/dept/historia/Agraria/Montagut\%201922.pdf.

20 For example, in 1921 the Chapter requested three millions cubic metres, at a rate of 3,000 for each of the thousand hectares to be watered. "Montagut. Canal de Aragón y Cataluña. 1906 y 1921”, P4B_M2_P1_C07, Arxiu Capitular de Lleida.
} 
Harvesting, measuring and

other expenses

$7,066.0$

4,273.0

$5,699.5$

$15,118.0$

4,295.2

Net income

103,809.5

$59,155.3$

$75,648.2$

$183,661.6$

$78,711.8$

Source: The 1856, 1860 and 1863 harvests, P5A_M3_P2_C07; the 1872 and 1875 harvests, P5B_M2_P5_C06, Arxiu Capitular de Lleida.

Between the mid $19^{\text {th }}$ century and the beginning of the crisis at the end of the century (table 5), the income from Montagut was based fundamentally on cereals (wheat and barley), as it was during the period of expansion in the $18^{\text {th }}$ century up to 1829 , and, to a lesser extent, on the grape harvest, that generated income equivalent to a tenth of that from barley and a fortieth of that from wheat. Little had changed in the distribution of crops compared with the 1780-1829 period, with very small quantities of alfalfa, potatoes, hemp and oil.

As we have seen, the licences from the first two decades of the $20^{\text {th }}$ century refer to the growing of hemp, maize and beet. The latter crop responded to the demand from Azucarera del Segre, in Menàrguens, in the Noguera district, from the beginning of the $20^{\text {th }}$ century. In 1958, there were references to the growing of hemp and rice. The approval of rice growing areas by the authorities responded to the need to feed the population in times of difficulties (Vicedo-Rius, 2000). Regarding alfalfa, the COCSA company was contracted in 1960 for the sale of alfalfa produced on 31.2 ha in the Camp d'Àguila and Cerdera Baixa areas. ${ }^{21}$

Table 6. Income from the land in the form of "terratge" received by the Chapter of Lleida

\begin{tabular}{lrrrrrr}
\hline & $1948-1949$ & & $1949-1950$ & & \multicolumn{1}{r}{$1951-1952$} \\
& $\mathrm{~kg}$ & pesetas & $\mathrm{kg}$ & pesetas & $\mathrm{kg}$ & pesetas \\
\hline Wheat & 75,998 & 189,995 & 99,232 & 248,080 & 119,031 & 302,278 \\
Barley & 25,965 & 51,930 & 34,478 & 68,956 & 47,918 & 95,836 \\
Oats & 23,215 & 46,430 & 25,567 & 51,134 & 68,198 & 136,396 \\
Red peas & 2,716 & 6,790 & 5,609 & 14,023 & 13,046 & 32,615 \\
alfalfa & 40,000 & 40,000 & 75,000 & 75,000 & 73,000 & 54,750 \\
Straw & 200,000 & 25,000 & & 20,000 & & 20,000 \\
Potatoes & 2,200 & 3,300 & 1,328 & 3,320 & 2,248 & 3,372 \\
Maize & 13,000 & 32,500 & 11,000 & 27,500 & 9,000 & 22,500 \\
Beans & 346 & 1,038 & 12 & 48 & 396 & 1,184 \\
Lima beans & 1,300 & 2,600 & 3,070 & 9,219 & 2,386 & 5,965 \\
Almonds & & 1,200 & 3,600 & 1,000 & 3,000 \\
Oil (litres) & & 600 & 6,000 & 800 & 9,600 \\
Grapes (arrobas) & & 1,237 & 11,133 & & \\
Millet & & 210 & 840 & & 687,496 \\
Alfalfa seed & & 24 & & 539,093 & & \\
Total & & & & & & \\
\hline
\end{tabular}

Source: Books "Diario". Cuentas, 1948-1952. P4B_M1_P1_C01, Arxiu Capitular de Lleida.

The "Diario" accounts books from Montagut give us information about the distribution of crops on the lands worked by the settlers from the income from the land paid according to the terms of the licences. The sharecroppers produced cereals, alfalfa and pulses, plus lesser proportions of oil and grapes. ${ }^{22}$ Rice stands out among the production directly by the canons, which reached 78,168 kg in 1948-1949, a much higher figure than in the following years.

The "Diario" from the same year specified that $1,800.82$ ha of the Montagut area were irrigated from the Aragon and Catalonia Canal, an 80-percent increase over the 1,000 ha that water was requested for in 1917. The 781.6 ha watered by the Pinyana irrigation ditch were more than double the 335.81 ha of 1808-1810. Thus, it must be emphasised that despite there still being 2,085.95 ha of dry land and hilly areas, a great effort had been made, mainly by the settlers as required in the clauses of the farming licences, to expand irrigation and guarantee that the harvests would not be lost through a lack of water.

The 1958 licences were done by CAFASA, as on 31 March 1953 the Chapter leased the Montagut estate to that company until 1960 to promote its settlement ${ }^{23}$. On 4 October 1956, the Comisión Capitular pro Colonización de Montagut (Chapter Commission for the Colonisation of Montagut) was created. Some years later, it agreed with

21 Pliego COCSA, P4B_M1_P1_C04, Arxiu Capitular de Lleida.

They also paid some amounts in cash for other crops but to a very limited extent.

23 There is a map with areas of transformation of Montagut from around 1960 in http://web.udl.es/dept/historia/Ägraria/The\%20Montagut\%20area\%20around\%201960.pdf. 
CAFSA to return the leased dry lands, as the chapter was levelling them to turn them into irrigated fields. In compensation, the chapter compensated the company annually until the end of the contract with $300 \mathrm{~kg}$ of red peas, 7,137 of regional wheat, 4,550 of barley and 7,509 of oats. Moreover, CAFASA held on to the pastures and half the income from hunting ${ }^{24}$.

The 1964 sharecropping contracts were written in the process of application of the 1956 General Colonisation Plan, which meant the expropriation of 2,192.83 Ha by the Instituto Nacional de Colonización (National Institute of Colonisation) in 1969. The canons sold the non-expropriated part, of good quality, to the Agrolérida company, which, as a result of some exchanges of land, also undertook to make improvements that were not always carried out, the cost then passing on to many sharecroppers, who had to make the investments to transform the dry lands into irrigated fields ${ }^{25}$.

\subsection{The relation between owners and farmers: the farming licences}

With the farming licences, the sharecroppers' leeway for negotiating with the owner was very limited. This was because the canons continued with the approach that ensured them a minimum income, in the line of the rentier practices seen in the final stage of the Old Regime. There is no doubt that a sharecropping contract was better for the peasantry than a monetary lease in an area with an annual rainfall of around $400 \mathrm{~mm}$, a long dry season (from June to September) and limited level of winter pastures that did not generate large amounts of organic fertilisers (Vicedo-Rius, Olarieta, \& Boixadera, 1999). Committing oneself to paying a fixed annual amount of money (unless this was a very small) was a risk that the holder of small and medium sized farms could not accept. ${ }^{26}$

The licences from Montagut explicitly state, in first place, that they do not give the farmers any right to the land. Although this is obvious in an economy based on private property from the $1840 \mathrm{~s}$, it is worth remembering that farming licences had been a characteristic contract for land in Lleida at least since the $17^{\text {th }}$ century and that, in the last third of the $18^{\text {th }}$ century, they were transformed into emphyteusis in perpetuity in many of the lordships ("encomiendas") that the Knights Hospitaller owned in western Catalonia plains ${ }^{27}$. When the licences were renewed for a family or lineage for long periods, the peasants could consider that they had acquired a right to the land. This occurred in the 1919 conflict between the farmers with licences in Safareig and Gatén and the Unión Laical de Propietarios and which led to the sale of these lands to the people who worked them in 1923 (Vicedo-Rius, 2004). To avoid these claims by the peasants, the licences to farm in Montagut were converted into sharecropping contracts -like those of $1964 .^{28}$

However, one of the main difficulties was that the investments by the licensed farmer were lost if his contract was rescinded and that was a possibility under contracts during the greater part of the period studied. The 1958 licences still stated that failure to observe any clause could mean the rescission of the contract with compensation. It still specifically stated that farmhouses, cabins or irrigation ponds could not be built without the permission of the owner, who did not contribute financially to building these and could demolish them if he believed it necessary without paying anything to the sharecropper. In the case of conflict, the later renounced his charter and had to accept what the owner's decision.

In addition, the income from land increased. While this was an eleventh or twelfth in the first half of the $19^{\text {th }}$ century, it later became an eighth, at a time when the tithes and primicies $^{29}$ had been abolished. In 1890 , it had been increased to a sixth in the case of grapes and a seventh for other products. The licences from 1909, 1922 and 1958 required a seventh in the dry-land areas, and a quarter in the irrigated lands. In 1922, it was stated that those of second quality would pay a fifth and the third class, a sixth. Finally, in 1964 a fifth was demanded, adding that the sharecropper had to pay for the seeds, fertilisers, wages and other expenses.

\subsection{The exploitation of the large ecclesiastical estates of the beneficiaries of Lleida Cathedral}

The licences to farm in Montagut during the hundred years after the mid $19^{\text {th }}$ century show that the canons were

${ }^{24}$ Contract with CAFASA for the lease of land for colonisation by the Excmo. Cabildo, in the Montagut property. Year: 1957, 58, 59, 60. P4B_M1_P1_C4, Arxiu Capitular de Lleida.

${ }^{25}$ For the process of colonisation of Montagut, see Bretón, V. (1990). Terra i franquisme a Lleida. Spain, Lleida: Pagès editors; ídem (2000). Tierra, Estado y Capitalismo. Spain, Lleida: Milenio.

${ }^{26}$ In the $18^{\text {th }}$ century, cash leases land occurred on irrigated lands. For example, in the Bages district of central Catalonia or the Horta de Lleida and its Segrià district. Ferrer, L. (1987). Pagesos, rabassaires i industrials a la Catalunya Central (segles XVIII-XIX). Spain, Barcelona: Publicacions de l'Abadia de Montserrat. Vicedo-Rius, E. (1997). "Emfiteutes, arrendataris, parcers i cultivadors amb 1licència. La contractació agrària a les planes occidentals catalanes, 1760-1860", Estudis d'Història Agrària, 11, 109-129.

27 "Propietat, formes d'accés a la terra i distribució dels ingressos", in Vicedo-Rius, E. (1991). Les terres de Lleida ...

${ }^{28}$ During the Spanish Second Republic, the Unión Laical de Beneficiados attempted to make this change which led to a serious conflict. Casasnovas, M., Domingo, M., Marco, J. and L. Bría (1966). ¿Concilio o rebeldía? Los latifundios clericales de Lérida, pp. 91 and after. Spain, Barcelona: Nova Terra. After the Civil War, in the Franco era, the licences of the beneficiaries were in the form of sharecropping.

29 A payment to the village priest. 
interested in the farmers improving the fields to enable irrigation, an obligation that was established generically. However, there were no specific requirements about the use of mineral and chemical fertilisers, and the production of certain products required authorisation from the administrators, who, from the 1890 licences, decided what crops should be sown. More specific were the clauses that established that the licences did not generate rights to the land, that the farmer could not sign agricultural contracts without permission and that set the income to be paid from the land. There were similar clauses in the contracts for the lands of the Beneficiaries of the Cathedral de Lleida. ${ }^{30}$ Comparing the description found in the assessments of Lleida of the estates of the beneficiaries, vegetables can be found as well as cereals in the distribution of crops in 1944, while in 1879 cereals and pastures dominated, together with a significant amount of fallow lands.

Table 7. Lands of the Beneficiaries of the Cathedral de Lleida according to the "Amillaramientos" (Assessments) of Lleida, 1879 and 1944.

\begin{tabular}{|c|c|c|c|c|c|c|c|}
\hline \multirow{3}{*}{ Place } & \multirow{3}{*}{$\begin{array}{l}\text { Area in } \\
\text { jornals } \\
\text { (ha) }\end{array}$} & \multicolumn{3}{|r|}{1879} & \multicolumn{3}{|c|}{1944} \\
\hline & & Value in & pesetas & Type of agriculture & Area & Cash & Type of \\
\hline & & sales & income & (textual description) & & & $\begin{array}{c}\text { (textual } \\
\text { description) }\end{array}$ \\
\hline Moredilla & $\begin{array}{c}915 \\
(400 \mathrm{ha})\end{array}$ & 30,000 & 2,110 & $\begin{array}{l}\text { Open field cereals and pastures. Irrigated by the } \\
\text { Urgell Canal and dry land a fifth part. There are } \\
450 \text { jornals that are sown one year and fallow the } \\
\text { following. }\end{array}$ & $\begin{array}{c}940 \\
(410 \mathrm{ha})\end{array}$ & 39,446 & $\begin{array}{l}\text { cereals and } \\
\text { vegetables } \\
\text { irrigated and } \\
\text { part dry }\end{array}$ \\
\hline Grealó & $\begin{array}{c}2.950 \\
(1,288 \mathrm{ha})\end{array}$ & 82,600 & 5,782 & $\begin{array}{l}\text { Open field cereals and pastures. Irrigated by the } \\
\text { Urgell Canal and dry land a twentieth part. There } \\
\text { are } 800 \text { jornals that are sown one year and fallow } \\
\text { the following. }\end{array}$ & $\begin{array}{c}3,100 \\
(1,357 \\
\text { ha) }\end{array}$ & 119,199 & $\begin{array}{l}\text { cereals and } \\
\text { vegetables } \\
\text { irrigated and } \\
\text { part dry }\end{array}$ \\
\hline Vinatesa & $\begin{array}{c}1666 \\
\text { (728 ha) }\end{array}$ & 52,479 & 3,673 & $\begin{array}{l}\text { Open field cereals and pastures. Irrigated by the } \\
\text { Urgell Canal and dry land an eighth part. There } \\
\text { are } 450 \text { jornals that are sown one year and fallow } \\
\text { the following. }\end{array}$ & $\begin{array}{c}1,666 \\
\text { (726 ha) }\end{array}$ & 83,200 & $\begin{array}{l}\text { cereals and } \\
\text { vegetables } \\
\text { irrigated and } \\
\text { part dry }\end{array}$ \\
\hline $\begin{array}{l}\text { Astó and } \\
\text { Cogullada }\end{array}$ & $\begin{array}{c}1473 \\
\text { (643 ha) }\end{array}$ & 39,852 & 2,490 & $\begin{array}{l}\text { Open field cereals and pastures. Dry land. There } \\
\text { are } 575 \text { jornals of farmed land that are sown one } \\
\text { year and fallow the following. }\end{array}$ & $\begin{array}{c}1,550 \\
(676 \mathrm{ha})\end{array}$ & 46,794 & $\begin{array}{l}\text { Dry land } \\
\text { cereals }\end{array}$ \\
\hline
\end{tabular}

Source: Amillaramiento de Lleida, 1879 y 1944, Arxiu Històric de Lleida.

The data obtained from the registers of the payment of the noveno (a cannon for irrigation paid to the Urgell Canal Board), offers a more detailed panorama. In Vinatesa between 1935 and 1943, there was an increase in the total irrigated area, but a fall in the sown open fields and a large rise in the area dedicated to vines and olive trees, and also those only under vines or olives, and to a lesser extent, alfalfa. Wheat and barley were the most important cereals. The increase in the percentage of hectares sown was basically due to the reduction in open fields. The percentages of fallow land went from 50 percent in 1935 to 145.7 in 1953 . While in 1935, fallow indicated that the land was difficult to farm and the option of investing in mineral and chemical fertilisers was not always chosen, biannual rotation being preferred instead, the 1943 figure is impossible in mathematic terms and should be interpreted as also referring to land that was not for sowing but which was not worked. The 1936-1939 Civil War must have been the cause of this drastic increase in the "non-agronomic fallow" areas.

The area of irrigated and open lands in Moredilla decreased, and vines, vines and olives and alfalfa increased

\footnotetext{
${ }^{30}$ For example, those from Gatén and Safareig in 1919, that I have been able to consult in "Término Safareig y Gatén. Los colonos de los términos de Safareig y Gatén se sublevan contra la Unión de Beneficiados de la S. I. Catedral de Lérida, para terminar con el tributo de sus cosechas, Cap. XIV, art. III, grupo B, archived in Cap. VII, art. II, grupo A, $\mathrm{n}^{\circ}$ 4, Arxiu del Canal de Urgell; or those of Astó and Cogullada, and Vinatesa, both for the 1949-1952 period, conserved in the Unión Laical de Beneficiados. Licencias de Aparceros", P3B_M2_P2_C01, Arxiu Capitular de Lleida.
} 
moderately. The area sown over open lands remained at about a third and the rest was fallow.

Table 8. Irrigated hectares and distribution of crops in the estates of the Unión Laïcal de Beneficiados (Lay Union of Benificiaries) in the municipal area of Lleida, 1935-1943.

\begin{tabular}{lcccccccccc}
\hline Place & Year & $\begin{array}{l}\text { Irrigated } \\
\text { hectares }\end{array}$ & $\begin{array}{c}\text { Open } \\
\text { land }\end{array}$ & $\begin{array}{c}\text { Vines } \\
\text { and } \\
\text { alives }\end{array}$ & $\begin{array}{c}\text { Vines } \\
\text { olives }\end{array}$ & $\begin{array}{c}\text { Alfalfa } \\
\text { Kitchen } \\
\text { gardens }\end{array}$ & Wasteland \\
\hline Vinatesa & 1935 & 486.6 & 361.3 & 24.3 & 17.1 & 6.9 & 40.5 & 0.0 & 36.4 \\
Vinatesa & 1943 & 548.7 & 212.6 & 61.2 & 184.6 & 35.0 & 47.4 & 0.4 & 7.6 \\
Moredilla & 1935 & 457.1 & 404.6 & 3.6 & 2.5 & 0.0 & 13.2 & 0.0 & 33.2 \\
Moredilla & 1943 & 404.3 & 251.0 & 25.4 & 34.2 & 0.0 & 31.0 & 0.0 & 62.7 \\
\hline Grealó & 1935 & $1,210.9$ & 708.6 & 3.9 & 18.2 & 7.4 & 107.9 & 0.0 & 365.0 \\
Grealó & 1943 & $1,140.9$ & 838.8 & 2.8 & 20.1 & 36.3 & 74.5 & 0.0 & 168.3 \\
\hline
\end{tabular}

\begin{tabular}{|c|c|c|c|c|c|c|c|c|c|c|}
\hline Place & Year & $\begin{array}{l}\text { Open } \\
\text { fields }\end{array}$ & $\begin{array}{c}\text { Hectares } \\
\text { sown }\end{array}$ & Fallow & Wheat & Barley & Oats & $\begin{array}{c}\text { Other } \\
\text { legumes }\end{array}$ & $\begin{array}{c}\text { Ha sown/ open } \\
\text { fields } \\
\% \\
\end{array}$ & $\begin{array}{c}\text { Fallow/ } \\
\text { open } \\
\text { fields } \\
\%\end{array}$ \\
\hline Vinatesa & 1935 & 361.3 & 162.4 & 187.9 & 110.5 & 33.3 & 16.1 & 2.5 & 44.9 & 52.0 \\
\hline Vinatesa & 1943 & 212.6 & 156.3 & 309.8 & 87.9 & 50.8 & 12.2 & 5.5 & 73.5 & 145.7 \\
\hline Moredilla & 1935 & 404.6 & 123.5 & 283.7 & 74.2 & 42.1 & 7.0 & 0.3 & 30.5 & 70.1 \\
\hline Moredilla & 1943 & 251.0 & 83.9 & 209.5 & 36.6 & 33.1 & 13.8 & 0.4 & 33.4 & 83.5 \\
\hline Grealó & 1935 & 708.6 & 276.9 & 385.4 & 188.0 & 69.9 & 18.4 & 0.6 & 39.1 & 54.4 \\
\hline Grealó & 1943 & 838.8 & 205.3 & 214.4 & 104.6 & 83.1 & 17.0 & 0.6 & 24.5 & 25.6 \\
\hline
\end{tabular}

Source: Quaderns del pagament del novè dels termes de Vinatesa, Moredilla y Grealó. Arxiu del Canal d' Urgell.

Only Grealó seems to have grown since 1935: despite a small reduction in the total irrigated area, there was an increase in the hectares of open fields, the presence of alfalfa, vines and olive trees was maintained, and, although the percentage of the area of open fields sown fell, so did the area of fallow land. The impact of the war on the area must be the reason for these apparent contradictions. The sum of the sown and fallow hectares is not 100 percent of the open fields, which leads to the conjecture that lands (for example, abandoned in reprisal against Republican sharecroppers' families), that were part of the irrigated area, were open fields, but were not counted as such, either as sown, or fallow, nor, of course, as barren. ${ }^{31}$

\subsection{Alternatives to exploitation of the large estates through farming licences}

Could the owners of the ecclesiastical estates have managed them differently? Undoubtedly. For example, by establishing the obligation to use specific quantities of mineral and inorganic fertilisers on the fields. The eighth clause of the contracts from the beginning of the $20^{\text {th }}$ century in Castell del Remei, a 600-hectare property belonging to the heirs of Don Ignacio Girona, a lineage that promoted the building of the Canal d'Urgell and very active in the Institut Català de Sant Isidre, (the Catalan land owners' association) stated: ${ }^{32}$

\footnotetext{
${ }^{31}$ For the post-war period in western Catalonia see, Mir, C. (2000), Vivir es sobrevivir. Justicia, orden y marginación en la Cataluña rural de posguerra. Spain, Lleida: Milenio.

32 "Para lograr regularidad y constancia en toda clase de cosechas, al procederse a la siembra, sea cual fuere la clase de cultivo que se emprenda, se emplearán 200 kilos de fosfato de cal por jornal de tierra, debiendo esta cantidad elevarse a 1.000 kilos cuando se siembre alfalfa, en atención a que la duración de esta leguminosa es de cuatro a cinco años.

Si durante dicho periodo de cuatro o cinco años en que se cultive alfalfa, el aparcero se vieses obligado por cualquier causa o motivo a a dejar las tierras confiadas a su cuidado, el propietario abonará el importe del abono, a prorrata del tiempo que falte para finir tal plazo, para que los intereses del aparcero no sufran perjuicio alguno.
} 
"To achieve regularity and constancy in all kinds of crops, on sowing, whatever the type of crop that is undertaken, 200 kilos of lime phosphate shall be applied per jornal of land, a quantity which must be increased to 1,000 kilos when alfalfa is sown, in attention that the duration of this leguminous plant is four or five years.

If during the aforesaid period of four or five years when alfalfa is grown, the sharecropper is forced by any cause or motive to leave the land entrusted to his care, the owner shall pay the cost of the fertiliser, in proportion to the time that remains for the end of the period, so that the interests of the sharecropper do not suffer any detriment.

For certain crops, especially for cereals, sodium nitrate, ammonium sulphate and sulphate of potash shall also be used as fertilisers, with prior agreement between the owner and the sharecropper regarding the quantity of each class that should be used."

The cost of the fertilisers was split equally between the owner and the sharecroppers, whose contract was for a year. In any case, these contracts from Castell del Remei transferred practically all the expenses to the sharecroppers, given that the owners, in the context of the end-of-the-century crisis with falling prices and rising salaries, opted to limit their investments in the land to the minimum (Garrabou, Planas, \& Saguer, 2001a).

Fertilising the land was one of the basic problems to be resolved on the western Catalan plain, given the relatively poor soils and the climatologic limitations that did not favour abundant pastures. It was habitual for owners to demand in the leases that the lessees carry out a number of hormigueros ${ }^{33}$ per unit of area or the equivalent in manure, before the introduction of inorganic fertilisers. It is also known, as seen in various surviving peasant notebooks, that hormigueros were habitual on the small and medium sized holdings (Garrabou \& Naredo, eds., 1996; Garrabou \& Gónzalez de Molina, 2010, eds.).

The Mancomunitat of Catalonia (1914-1925) carried out promotional and agrarian extension work (Mancomunitat de Catalunya, 1923) both through publishing leaflets and holding sessions in various Catalan districts. The institution promoted the new mineral and chemical fertilisers at ever more affordable prices among farmers (Pujol, 1998). The setting up of syndicates-cooperative during the first third of the $20^{\text {th }}$ century allowed the peasants to obtain supplies at affordable prices.

Given all the above, it is surprising that there are no explicit references to the use of fertilizers to improve the yields in the licences of Montagut or in those of the Beneficiaries. As can be seen in the contract from Castell del Remei, the length of the contract was no source of difficulty, as the owner would indemnify the sharecropper who had fertilised for a full cycle of alfalfa and who does not finish it. Garrabou, Planas, \& Saguer (2001a) have argued that sharecropping is a form of agrarian contracting that adapts to specific situations and times and should not be interpreted as an element of backwardness.

The licences to farm ended up lasting for three years, and after the first, they could be cancelled either party. As in Castell del Remei. All this seems to indicate that it was the management of the ecclesiastic estates that did not facilitate the agrarian transformations and, in the case of Montagut, the state would have to intervene to modernise them, although it was the tenants who were economically damaged.

Safareig and Gatén are examples that show that sharing the land from the estates among the peasantry without any or with very little land of their own would have been a better option, not only socially but also economically. When the lands of the Chapter were prepared for auction in 1843-1844 (except Montagut, and before they were transferred to the Beneficiaries), the state surveyors reported that Safareig and Gatén were farmed by tenants. They referred to each farmer's piece of land, the income it produced, and there was no reference (as happened in the other areas surveyed) to lands that were only good for pastures. ${ }^{34}$

Maintaining the same families on the same lands despite the insecurity of the contracts generated demands by the peasantry who felt they had a right to own the land. In 1918 and 1919, the sharecroppers stopped paying an eighth of their crop (the income from the land that the farming licence required) arguing that as they paid the catastro (property tax), they were the legal owners and this eighth was a levy that should be abolished. Graph 5 shows that, as well as the

Para determinados cultivos, especialmente para los cereales, se emplearán además como abonos, el nitrato de sosa, el sulfato amónico y el sulfato de potasa, poniéndose de cuerdo previamente el propietario y el aparcero respecto la cantidad que de cada clase deba emplearse".

"Contrato de Aparceria que rige en la finca de Hijos de Don Ignacio Girona....", in Bayer Bosch, J. (1904: 249-252).

33 In Catalan, "formiguer" or "boïc". This was the partial burning of material (from pruning, dry leaves secas, etc.) covered with lumps of earth. The remains of the earth and the ash were scattered on the land. It contributed to cleaning the fields, supplied a limited amount of fertilisation but the remains of charcoal contributed to retaining water, essential in an area with a dry climate. Olarieta, J.R., et al. (2010), "Hipótesis y primeros resultados sobre los hormigueros como técnica de fertilización en los sistemas agrarios", in Garrabou, R. and González de Molina, M., eds., La reposición de la fertilidad en los sistemas agrarios tradicionales, pp.109-126. Spain, Barcelona: Icaria.

34 "Secretaría de la Junta de Admón. y Venta de Bienes del Clero Secular, Lleida, 19 March 1844". 
lands in their place of origin, the sharecroppers held a limited amount of irrigated land in Safareig and Gatén, generally less than three hectares.

After the 1918-1919 conflict between the farmers with licences in these properties, mostly in Bellvís, whose municipality they belonged to, and the Unión Laical de Beneficiados, an agreement was reached in 1923 under which the settlers could buy the land from the beneficiaries at an agreed price. After 1923, these peasants were able to manage their properties, as many of them already did, without fear of losing their land and investing manpower and capital to obtain greater yields and better living conditions, until the 1936 Civil War wiped out much of the progress made at a stroke.

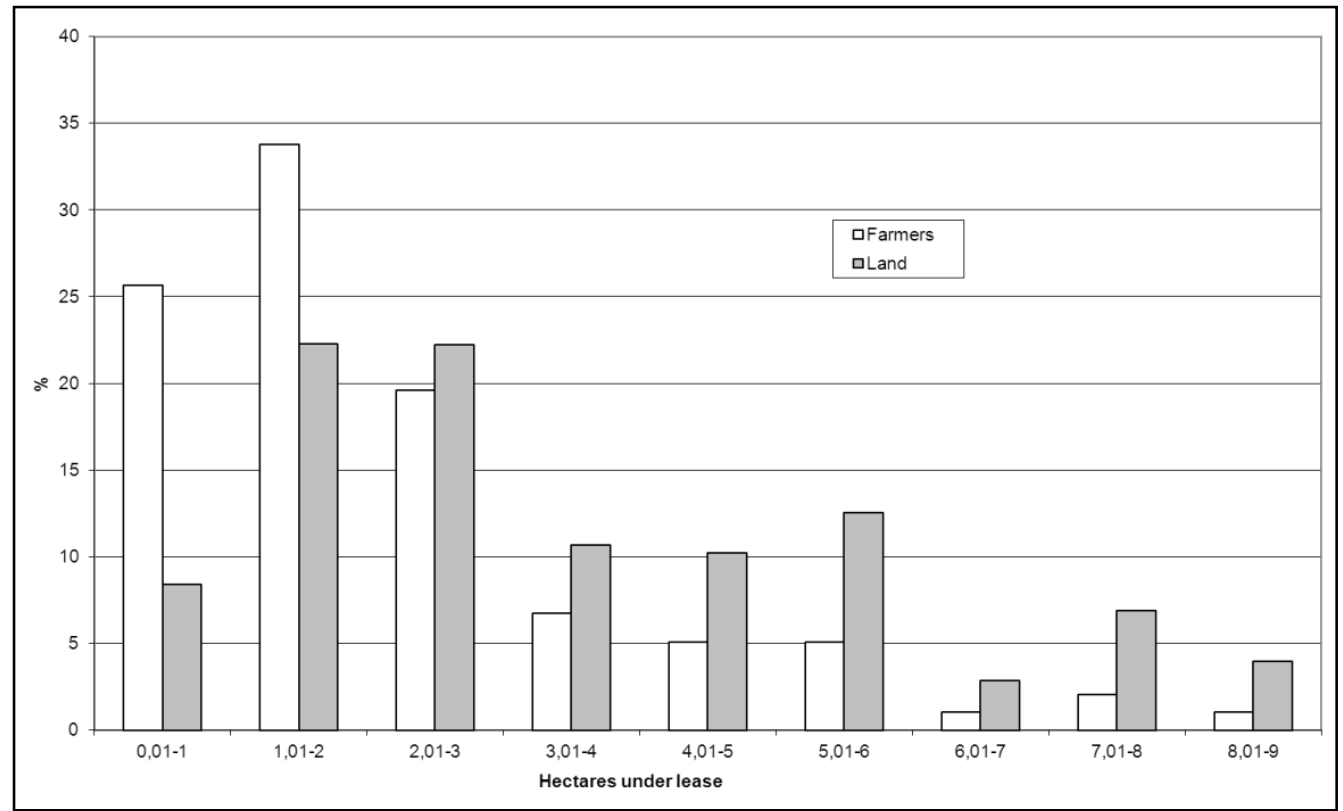

Graph 5. Farmers with licence and land held for each size of holding in Safareig and Gatén, 1910s, in \%

Source: Taken from Vicedo-Rius, E. (2004), "Los aparceros y su lucha contra la Unión Laical de Beneficiados. El conflicto de Gatén y Safareig durante el primer tercio del siglo XX", table 2, p. 1294, in Josep Fontana. Història i projecte social, pp. 1286-1299. Spain, Barcelona: Crítica.

The sale of the land from the remaining estates to the farmers on it was considered the best option by the beneficiaries, due of the pressure from the sharecroppers in Vinatesa, La Cogullada, Moredilla and Grealó. This process included the passing of the Llei de contractes de cultiu (Law of farming contracts) by the Generalitat de Catalunya, the regional government, in 1934. Although this was fundamentally aimed at satisfying the demands for stability among the rabasaires (vine growers), the farmers with licence from the beneficiaries demanded the application of a law that awarded the right to purchase to peasants who had had contracts for over eighteen years (Balcells, 1968; Barrull, 1986). In 1935, an agreement was reached about the price to be paid. The negotiations between the Chapter and the sharecroppers in Montagut were meant start on the 18th of July 1936, the same day that the military rebellion broke out. The process was stopped.

It was not until the end of the 1960s that the beneficiaries finally sold the land to the sharecroppers, after strong internal pressure by a group of priests who considered these properties incompatible with Christianity (Casasnovas, Domingo, Marco, \& Bría, 1966) and society in general. ${ }^{35}$ As we have seen above, the sharecroppers of Montagut were displaced and had to invest heavily to transform their new lands into irrigated areas.

\section{Conclusion}

The depopulation caused by the $17^{\text {th }}$-century crisis in western Catalonia plains facilitated the maintenance of large estates mainly in the hands of ecclesiastical lords. The liberal agrarian reform in the lands in Lleida not only failed to share out a single jornal of land among the most marginalised peasantry (small peasant landowners and salaried

35 Placards appeared with the text: "Canteu senyors canonges, i rics beneficiats; canteu de dia i nit sempre desafinats; canteu la hipocresia amb nom de santedat. Canteu, canteu, però sapigueu, que'l Christ de la veritat no canta al vostre costat... !” (Sing gentlemen canons, and rich beneficiaries; sing by day and by night and always out of tune; sing your hypocrisy in the name of sainthood. Sing, sing, but you should know that the Christ of the truth does not sing along with you... ?") 
workers) but also most of the estates belonging to the Chapter of Lleida came into the hands of the Beneficiaries from the same cathedral. It has been shown that the licences to farm in Montagut during the period under study did not include explicit clauses with agronomic contents that could have led to an improvement in yields and production, except with regard to the extension of irrigation. The licences from the Beneficiaries for Vinatesa, Grealó, Els Olomins, La Cogullada, Astó, Safareig and Gatén are very similar, although they do not require the land to be adapted to irrigation, surely because being watered from the Canal d'Urgell, these activities were carried out by other means and not always at the same rate. The contracts in Safareig and Gatén suggest that most of the land had already been adapted to irrigation.

Was it right to use sharecropping contracts to work the large ecclesiastical estates? Compared with a fixed monetary contract, they undoubtedly reduced the risk that the farmer assumed in an area with a Mediterranean/continental climate in which crops could be lost through drought or frost. As Hayami \& Otsuka (1993) argue, the fixed-rent contract would be preferable when the owner has difficulties enforcing the contract and there is a risk-neutral, while the share contract would be better under this conditions of risk. The latter contract does not mean less efficiency in a legal framework in which all the contractual options exist. If it was not used on the dry lands or new irrigation, ${ }^{36}$ as did happen in the traditional irrigated area of the western Catalan plain, this was surely because it would require demanding a lease much lower than the annual average sharecropping could supply. Hayami and Otsuka suggested that the income in the share contracts was greater than in the fixed-rent contracts.

For Catalonia as a whole, Garrabou, Planas, \& Saguer (2001a) consider sharecropping as a contract that was, in itself, no hindrance nor advantage for economic growth and define it as a very useful instrument for enriching the well-off owners who used it. Singh (1989) has shown that the share contracts were useful mechanisms for assigning the useful resources efficiently in function of the structure of the information available.

Thus, what happened with the contracting in the framework of the management of the ecclesiastic estates on the western Catalonia plain? The conclusions are summarised in the following points:

1). Sharecropping formulated as a farming licence maintains many of the inertias it had under the Old Regime, playing the role of guaranteeing an income although low. However, perhaps the main point is that the ownership does not assume a management of the farm in line with the progress-taking place in contemporary agriculture. The lack of obligations regarding fertilization is surprising when it was a constant element in the contracts in the area.

2). It was not only that they did not take on the management but also impeded, through the clauses that facilitated the cancellation of the contract, the sharecropper from making a whole series of improvements. To the extent that towards the end of the period studied only the first of the three years contracted was guaranteed, they could be expelled for any breach of the contract, and the infrastructures they built had to have permission and could be demolished by the Chapter in the case of Montagut. In Safareig and Gatén, the sharecroppers would receive no compensation for any plantations of vines or olive trees they did if they were expelled or waived the contract. In Astó and Cogullada in 1952, compensation is mentioned if the improvements had been authorised in writing by the beneficiaries. This situation is very different from the one presented by Allen and Lueck (2002) considering sharecropping. The sharecropper paid all the inputs or did so in the same proportion as the share of the output. The costs of seeds and fertiliser, acquired on the market, tended to be shared. On the large ecclesiastical estates, there was no reference to the purchase of these inputs, which indicates a lack of interest by the owner and thus a limited investment by the sharecropper given the high risk of losing the capital invested.

3). In the same study, Allen and Lueck emphasise the advantages of long contracts for achieving more balanced agreements between the two parties. Short contracts generally favour the lessor. In our case, the short contracts favoured the lessor relatively little as the sharecroppers avoided investments for the reasons mentioned above. Moreover, most of the clauses of the contracts were very restrictive about the activities of the sharecropper and had little agronomic contents in the sense of encouraging improvements in the working of the land.

4). The exception was in the first half of the $20^{\text {th }}$ century. There was a significant increase in the irrigated areas in Montagut from both the Aragon and Catalonia and Pinyana canals although there were still large areas of dry-land farming and hilly areas in 1950. This expansion was fundamentally due to the work required in the sharecroppers' farming licences, who were not paid anything for building verges, irrigation ditches and drains, in a context of a steady rise in the shares of fruit required as income from these contracts.

5). The sharecroppers of Safareig and Gatén, who had achieved a certain stability on the land despite the temporality

\footnotetext{
36 As table 8 shows, the fallow area were important in the 1930s and 1940s, which shows the difficulties of introducing irrigation to areas with bad or low quality land despite being part of the area irrigated by the Urgell canal since the 1860s. Vicedo-Rius, E., J. Boixadera, J.R.Olarieta and J.M. Martínez (2008), "Las transformaciones territoriales del área rural de Lleida, 1750-1950"...
} 
expressed in the farming licences, opted for refusing to pay rent on the basis that they were the owners as it was they who paid the catastro (state tax on the ownership of the land). The conflict came to a head in 1919 and only four years later, a purchase agreement was reached with the beneficiaries. It would then be the new peasant owners who, like any other landowner in the area watered by the Canal de Urgell, decided what to adventure, what to invest, what to produce, with the guarantee of not leaving the safety of their capital to the whims of the beneficiaries. The good working of the peasant farms is shown in the arguments that the beneficiaries used before the judge in $1919^{37}$.

6). During the $2^{\text {nd }}$ Republic, an agreement was reached to buy the rest of the lands from the beneficiaries and there were plans to begin discussions for the sale by the canons of the lands in Montagut ceded under framing licenses. All this was thwarted by the Civil War of 1936-39 and the posterior dictatorship until the 1960s, when, under strong social pressure influenced by the renovation of the $2^{\text {nd }}$ Vatican Council and the clandestine agrarian syndicalism, the process of purchasing by the sharecroppers from the beneficiaries was carried out, with the theme of the sharecroppers of Montagut remaining unresolved. ${ }^{38}$

\section{Acknowledgements}

This paper was made possible by a grant from the Spanish government's Ministerio de Economía y Competitividad [HAR2009-13748-C03-02, HAR2012-35022 and HAR2015-65870-R]. The maps were prepared by the Cartography Laboratory at the Universitat de Lleida.

\section{References}

Allen, D. W., \& Lueck, D. (2002). The Nature of the Farm. Contracts, Risk, and Organization in Agriculture. USA, Boston: The MIT Press.

Balcells, A. (1968). El problema agrari a Catalunya, 1890-1936, la qüestió rabassaire. Spain, Barcelona: La Llar del Llibre.

Barrull, J. (1986). Les comarques de Lleida durant la Segona República (1930-1936). Spain, Barcelona: L'Avenç.

Casasnovas, M., Domingo, M., Marco, J., \& L. Bría (1966). ¿Concilio o rebeldía?. Los latifundios clericales de Lérida. Barcelona: Nova Terra.

Congost, R. (1990). Els propietaris i els altres. La regió de Girona 1768-1862.Spain, Vic: Eumo;

Congost, R., Planas, J., Saguer, E., \& Vicedo, E. (2010). ¿Quién transformó la agricultura catalana? Los campesinos como actores del cambio agrario en Cataluña, siglos XVIII-XX?", in A.A.V.V., Sombras del progreso. Las huellas de la historia agraria. Ramón Garrabou, 171-198. Spain, Barcelona: Crítica.

Dios, Salustiano de (1999). Historia de la propiedad en España, siglos XV-XX. Spain, Madrid: Colegio de Registradores de la Propiedad y Mercantiles de España.

Dios, Salustiano de (2002). Historia de la propiedad en España: bienes comunales, pasado y presente. Spain, Madrid: Colegio de Registradores de la Propiedad y Mercantiles de España.

Ferrer, L. (1987). Pagesos, rabassaires $i$ industrials a la Catalunya central (segles XVIII-XIX). Spain, Barcelona: Publicacions de l'Abadia de Montserrat.

Flórez Estrada, A. (1836). "Del uso que debe hacerses de los bienes nacionales", Obras de Alvaro Flórez Estrada, I, 359-364. Madrid: Ediciones Atlas, Biblioteca de autores españoles, 1836, republished in 1958.

Garrabou, R. (1992, ed.). Propiedad y explotación campesina en la España Contemporánea. Spain, Madrid: MAPA.

Garrabou, R., \& Naredo, J. M. (1996.). La fertilización en los sistemas agrarios. Una perspectiva histórica. Spain, Madrid: Fundación Argentaria / Visor.

Garrabou, R. and González de Molina, M., (2010). La reposición de la fertilidad en los sistemas agrarios tradicionales. Spain, Barcelona: Icaria.

Garrabou, R., Planas, J., \& Saguer, E. (2001). "Sharecropping and the management of large rural estates in Catalonia, 1850-1950", The Journal of Peasant Studies, 28-3, 89-108.

\footnotetext{
37 For example, the beneficiaries stated that "Thus, they exercise a true providence and social mission with the most wretched and all without distinction, as, except in exceptional and serious graves cases, they do not withdraw the lands from the tenants, constituting "real family assets" which they live off, and that, not being theirs, they cannot rent or transfer". "Moreover, many give these lands to their children when they come of age. With the permission and authorisation of the owners, they cede the lease of part of the estate that the Beneficiaries transferred in their name under a new contract". in "El conflicto de Gatén y Safareig, Lérida 23 de julio de 1919", in Término Safareig y Gatén....

38 A large part of the Montagut area was worked without sharecroppers and as a capitalist property with centralised management.
} 
Garrabou, R., Planas J., \& Saguer, E. (2001b). Un capitalisme impossible? La gestió de la gran propietat agrària a la Catalunya contemporània. Spain, Vic: EUMO.

Garrabou, R. et al. (2011), Acceso a la propiedad y desigualdad social en el mundo rural catalán de mediados del siglo XIX. [http://www.seha.info/congresos/2011/S2-Garrabou\%20Ramon.pdf].

Garrabou, R., J. Planas, J., Saguer, E., \& Vicedo, E. (2014), "Propiedad de la tierra y desigualdad social en el mundo rural catalán de mediados del siglo XIX”, Historia Agraria, 63, 115-150.

Hayami, Y., \& Otsuka, K. (1993). The economics of contract choice. An agrarian perspective. UK, Oxford: Clarendon Press.

Mancomunitat de Catalunya (1923). L'obra realitzada: anys 1914-1923. Spain, Barcelona: Mancomunitat de Catalunya. Giralt, E. and R. Garrabou, (2006, dirs). Segles XIX i XX, 4, Història Agrària dels Pä̈sos Catalans. Spain, Barcelona: Universities of Catalan Countries.

Mir, C. (2000). Vivir es sobrevivir. Justicia, orden y marginación en la Cataluña rural de posguerra. Spain, Lleida: Milenio.

Olarieta, J. R., et al. (2010). "Hipótesis y primeros resultados sobre los hormigueros como técnica de fertilización en los sistemas agrarios", in Garrabou, R. and González de Molina, M., eds., La reposición de la fertilidad en los sistemas agrarios tradicionales, 109-126. Spain, Barcelona: Icaria.

Pujol, J. (1998). "La difusión de los abonos minerales y químicos hasta 1936: El caso español en el contexto europeo", Historia Agraria, 15, 143-182.

Rueda-Hernanz, G. (1997). La Desamortización en España: un balance, 1766-1924. Spain, Madrid: Arco/Libros.

Serra, E. (1983). "Notes sobre els orígens i l'evolució de l'emfiteusi a Catalunya”, Estudis d'Història Agrària, 7, 127-138.

Singh, N., \& Bardhan, P. K. (1989). The economic theory of agrarian institutions, 33-72. UK, Oxford: Clarendon Press.

Tello, E. (1995). Cervera i la Segarra al segle XVIII. En els orígens d'una Catalunya pobra, 1700-1860. Spain, Lleida: Pagès editors.

Vicedo-Rius, E. (1991). Les terres de Lleida i el desenvolupament català del set-cents. Producció, propietat $i$ renda. Spain, Barcelona: Crítica.

Vicedo-Rius, E. (2000). "La comunitat central de regants del Canal de Pinyana i Sèquia de Fontanet: noves institucions i vells conflictes en els recs del segrià (anys cinquanta del segle XX)", in Vicedo-Rius, E., ed., Terra, aigua, societat $i$ conflicte a la Catalunya Occidental, pp. 215-237. Spain, Lleida: Pagès Editors.

Vicedo-Rius, E. (2004). "Los aparceros y su lucha contra la Unión Laical de Beneficiados. El conflicto de Gatén y Safareig durante el primer tercio del siglo XX”, in Josep Fontana. Història i projecte social, 1286-1299. Spain, Barcelona: Crítica.

Vicedo-Rius, E. (2008). "Mercado y precios. El almudí de Lérida, 1700-1833”. Historia Agraria, 45, 53-88.

Vicedo-Rius, E. (2009), "Les terres del Capítol i dels Beneficiats de la Catedral de Lleida als segles XIX i XX”, Temps de llums i ombres. Temps d'esperança. L'època contemporània. Del segle XIX fins als nostres dies. Volume IV of Arrels Cristianes, 305-314. Spain, Lleida: Pagès editors - Bisbat de Lleida.

Vicedo-Rius, E., Boixadera, J., \& Olarieta, J. R. (1999). “Sistema hidráulico, organización de los riegos y usos del agua en la huerta de Lleida (1830-1950)", in Garrabou, R. and J. M. Naredo, El agua en los sistemas agrarios., $225-254$. Spain, Madrid: Argentaria/ Visor distribuciones.

Vicedo-Rius, E., Boixadera, J., Olarieta, J. R., \& Martínez, J. M. (2008). "Las transformaciones territoriales del área rural de Lleida, 1750-1950", in Garrabou, R. and J.M. Naredo (ed.). El paisaje en perspectiva histórica. Formación y transformación del paisaje en el mundo mediterráneo, 163-186. Spain, Zaragoza: Prensas Universitarias de Zaragoza. Co-edition with the Sociedad Española de Historia Agraria.

Vilar, P. (1966). Catalunya dins I'Espanya Moderna, vs. III and IV. Spain, Barcelona: Edicions 62.

\section{(cc) $\mathrm{BY}$}

This work is licensed under a Creative Commons Attribution 3.0 License. 